BANCA D'ITALIA

E U R O S I S T E M A

Temi di discussione

(Working Papers)

The international transmission of US tax shocks:

a proxy-SVAR approach

by Luca Metelli and Filippo Natoli 



\section{BANCA D'ITALIA}

E U ROS I S T E MA

The international transmission of US tax shocks: a proxy-SVAR approach

by Luca Metelli and Filippo Natoli

Number 1223 - June 2019 
The papers published in the Temi di discussione series describe preliminary results and are made available to the public to encourage discussion and elicit comments.

The views expressed in the articles are those of the authors and do not involve the responsibility of the Bank.

Editorial Board: Federico Cingano, Marianna Riggi, Emanuele Ciani, Nicola Curci, Davide Delle Monache, Francesco Franceschi, Andrea Linarello, Juho Taneli Makinen, Luca Metelli, Valentina Michelangeli, Mario Pietrunti, Lucia Paola Maria Rizzica, Massimiliano Stacchini.

Editorial Assistants: Alessandra Giammarco, Roberto Marano.

ISSN 1594-7939 (print)

ISSN 2281-3950 (online)

Printed by the Printing and Publishing Division of the Bank of Italy 


\title{
THE INTERNATIONAL TRANSMISSION OF US TAX SHOCKS: A PROXY-SVAR APPROACH
}

\author{
by Luca Metelli ${ }^{*}$, Filippo Natoli*
}

\begin{abstract}
We investigate the international propagation of tax rate shocks originating in the United States using a global vector error-correction model (GVAR). We identify shocks to corporate and personal income tax rates by using narrative series as external instruments, following the proxy-SVAR methodology. The main results of the paper are the following: (1) the domestic effects of corporate tax shocks are stronger than those of personal income tax shock; (2) spillovers are in most cases positive and significant, albeit of small size; (3) the boost to exports in recipient economies, stimulated both by stronger US demand and by real exchange rate depreciation vis-à-vis the US dollar, is the main transmission channel; financial channels (through long-term interest rates) also play a role.
\end{abstract}

JEL Classification: C22, E62, F42.

Keywords: international fiscal spillovers, proxy SVAR, GVAR.

\section{Contents}

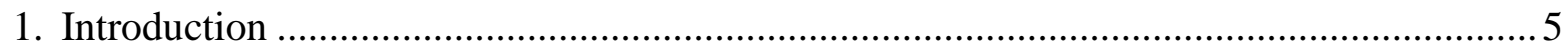

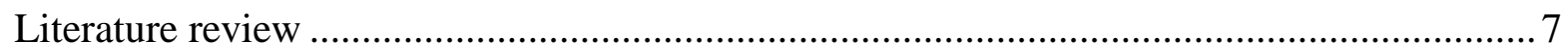

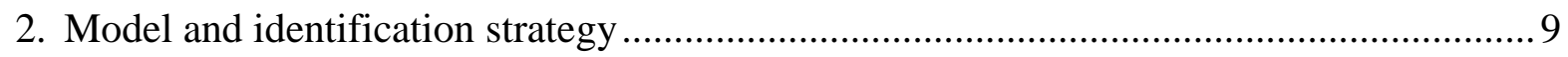

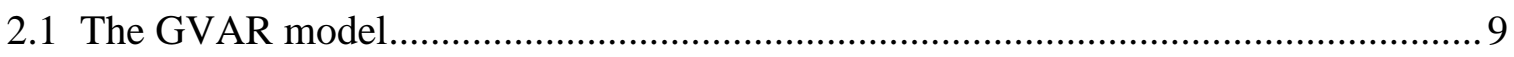

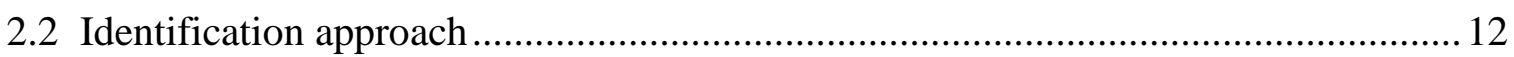

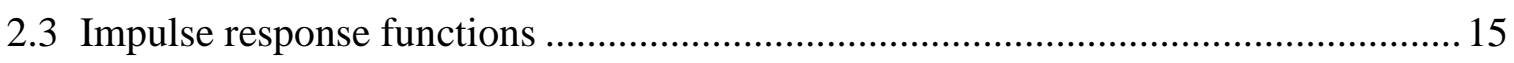

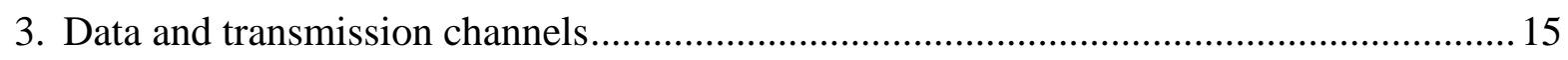

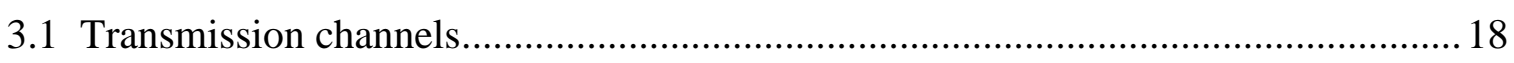

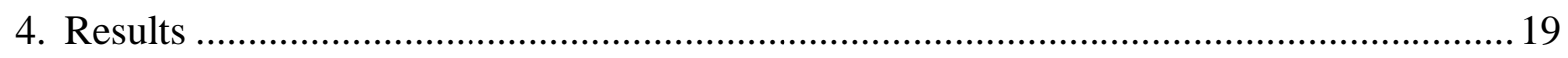

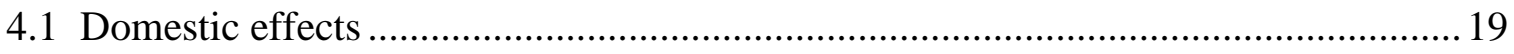

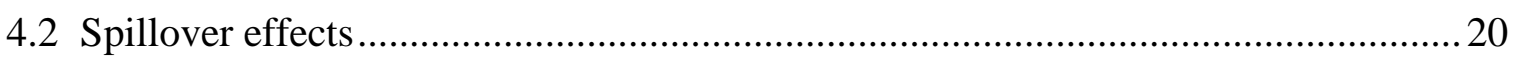

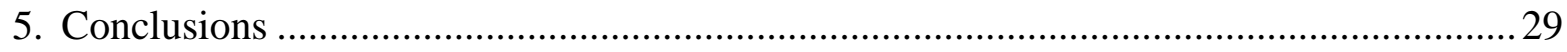

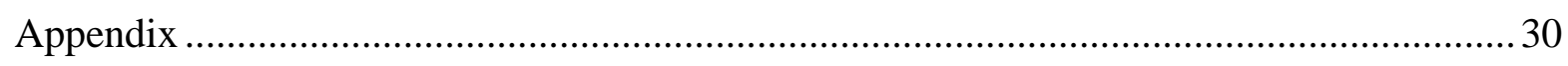

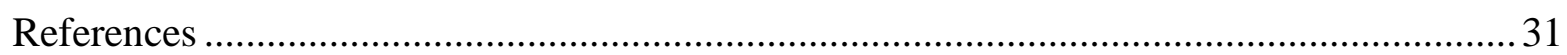

\footnotetext{
* Bank of Italy, Directorate General for Economics, Statistics and Research.
} 



\section{Introduction $^{1}$}

Since the Great Recession, the discussion on the role of fiscal policy has gained traction, as discretionary fiscal measures have started afresh to serve as policy tools in advanced economies. During the global financial crisis, the US administration implemented a sizeable fiscal stimulus, which supported the recovery in the United States; in contrast, during the Euro area debt crisis many countries in Europe introduced tax increases and spending cuts as a way to restore confidence in the sustainability of public debt. The US Congress has recently adopted a major overhaul of the tax code, embracing tax cuts and increases in military spending.

The renewed interest in fiscal policy has spurred considerable academic research on its effects on economic activity. However, with much of the debate concentrated on the domestic effects, much less has been said on the international dimension of fiscal policy and its spillovers. We take up this issue by focusing on spillovers from tax policy that, differently than spillovers from government spending, have been mostly disregarded in the fiscal policy literature. We evaluate the domestic and spillover effects of an expansionary tax rate shock in the United States, focusing on the international channels of transmission. Our analysis provides answers to some relevant policy questions, such as: does a fiscal expansion in the US increase output abroad? Is there heterogeneity in the transmission across recipient countries? Are spillovers driven by real or financial channels? Also, we provide evidence on how the impact of fiscal policy depends on the specific instrument adopted, comparing specific components of tax policies. Are corporate and personal income tax shocks both effective? Are their effects equally persistent? Do they propagate through the same channels?

We answer these questions within a global vector error-correction model (GVAR), the framework developed by Pesaran et al. (2004), in which each country model features domestic and foreign variables. Target variables are real GDP, inflation, real equity prices, interest rates, real exchange rates and exports. In the US model, we also include fiscal variables, and identify tax rate shocks following the proxy-SVAR methodology. For this purpose, we use the narrative series of Mertens and Ravn (2013) as instruments for personal and corporate income tax rate shocks. The main results of the paper are the follow-

\footnotetext{
${ }^{1}$ We thank Maria Grazia Attinasi, Pietro Catte, Valerio Ercolani, Laurent Ferrara, Andrea Finicelli, Alessandro Galesi, Andrea Gazzani, Ethan Ilzetzki, Daniele Siena, Vanessa Smith and seminar participants at the European Central Bank for their helpful comments and suggestions. The views expressed in this paper are those of the authors and do not necessarily reflect those of the Bank of Italy. All the remaining errors are ours. E-mail: luca.metelli@bancaditalia.it, filippo.natoli@bancaditalia.it.
} 
ing. First, the domestic effects of tax rate shocks are strong, with multipliers consistently above unity one year after the shock. This result is in line with Ramey (2017), showing that tax shocks have an impact on output that is even stronger than that of a spending shock. ${ }^{2}$ Second, spillovers are positive and, in most cases, statistically significant, albeit of a small size. Third, in terms of geographical distribution, US tax shocks have a stronger impact on advanced than emerging countries; moreover, economies that are geographically close to the US are not impacted in the same way, with Mexico benefiting less than Canada from the US fiscal expansion.

This paper also sheds light on the international transmission mechanism of US fiscal policy. The main channel through which fiscal shocks propagate is international trade. Independently of the type of shock, following a fiscal expansion the United States increases its imports from the rest of the world, stimulating output in foreign countries. This occurs via both a price and a quantity effect. Indeed, for some countries real exchange rates depreciate vis-à-vis the US dollar, improving their price competitiveness (expenditure switching or price effect); for other countries, higher US output stimulates demand for imports without significant exchange rate variations (expenditure boosting or quantity effect). Financial channels (through interest rates and equity prices) also play a role in the international transmission, although a smaller one than the trade channel. Foreign long-term interest rates generally increase following the US fiscal shocks, acting as a drag on economic growth; only in a few cases they fall on impact reinforcing expansionary effects, as suggested by the literature focusing on fiscal policy reversals as the key driver of domestic and international responses (see Literature Review). Concerning equity markets, a US fiscal expansion may lead to an increase in foreign equity prices, generating positive wealth effects which, in principle, could support consumption and investment; however, in our framework the response of equity prices to fiscal shocks is generally not significant, suggesting that wealth effects are of minor importance in channeling fiscal shocks across the board.

This paper contributes to the recently growing literature on fiscal spillovers in several ways. First, it is one of the first studying empirically the international transmission of fiscal shocks originating in the US, in particular for what concerns tax shocks. As we model the world economy in a single framework, we are able to take into account the indirect effect of shocks arising from the economic linkages among recipient countries (third-party effects), and obtain more accurate spillover estimates than those delivered by widely-used bilateral models (such as two-country VARs or local projections à la Jorda,

\footnotetext{
${ }^{2}$ This result is not uncontroversial. For a different point of view, see Caldara and Kamps (2017).
} 
2005), as highlighted by Georgiadis (2017). Second, the paper highlights the differences in the international propagation among the implemented tax policy tools, i.e. personal and corporate income tax policies. Third, it is the first paper quantifying spillovers in terms of fiscal multipliers for each type of tax shocks and at different points in time. Fourth, fiscal policy shocks in the US are identified using narrative series, which allow for the identification of tax rate shocks, as opposed to the more endogenous measure of tax revenues usually adopted in the literature on fiscal spillovers. As far as we know, this is also the first time a proxy-SVAR identification strategy is employed in a GVAR framework.

\section{Literature review}

The paper draws on different strands of literature. First, it relates to the literature analyzing international fiscal spillovers, in particular to the very scant literature analyzing tax spillovers. The closest paper to ours are Blagrave et al. (2018) and Christofzik and Elstner (2018). Blagrave et al. (2018) investigates spillovers stemming from a global fiscal shock (both spending shock and tax revenue shock), aggregated across five advanced economies; by running the local projection estimates of Jorda (2005) on the GDP of each recipient economy separately, the paper finds that spillovers depend on the monetary policy response (in particular at the zero lower bound) and on the degree of economic slack in source and recipient countries. Although it addresses the relevant issue of the state-dependency of fiscal policy effectiveness, Blagrave et al. (2018) focus on the more endogenous variable tax revenues instead of tax rate shocks. Moreover, they do not concentrate on the transmission mechanism of fiscal shocks, which is instead our focus. Christofzik and Elstner (2018) analyze the spillover effect of tax rate shocks, identified as in our case through the methodology of Mertens and Ravn (2013). They find positive but small spillovers on German output, also considering the reaction of the German fiscal variables. This study, contemporaneous to our, is also the closest. However, it focuses only on the German economy, neglecting the whole international dimension. Aside from these two papers, most of the literature on fiscal spillovers concentrates on government spending. Auerbach and Gorodnichenko (2013) estimate government spending spillovers in a panel of OECD countries; they find, in line with Blagrave et al. (2018), positive effects on foreign output. Bussiere et al. (2017) use a three-country specification of the Global Integrated Monetary and Fiscal (GIMF) model of the IMF to simulate different types of budget-neutral spending policies in the US; they find positive domestic and spillover effects, that can be amplified in case of a coordinated action across countries, and a trade-off 
between growth and distributional consequences. Faccini et al. (2016) estimate spillovers from a US government spending shock in a factor model, finding positive and sizable effects on foreign output operating mainly through a financial channel, i.e. a reduction of real interest rates abroad. This paper follows some theoretical and empirical papers claiming that expectations of future spending reversals, triggered by fiscal rules on debt, are such that the effect of expansionary shocks on domestic interest rates, positive in standard models, is instead negative and acts as the main driver of fiscal expansion in the medium run. ${ }^{3}$ According to this literature, spillovers are mainly determined by the evolution of the foreign interest rates determined by international financial linkages (Corsetti et al., 2010; Corsetti et al., 2012a; Corsetti and Muller, 2013; Ong, 2018). While we find some negative effects on long rates in the case of corporate tax shocks, in our paper the international transmission goes mainly through the trade channel. In this respect, our results are more in line with those of papers that investigate fiscal spillovers indirectly, i.e. by studying the reaction of those domestic variables that can influence foreign output dynamics, such as the exchange rate (e.g., Auerbach and Gorodnichenko, 2016, Forni and Gambetti, 2016), the trade balance (e.g., Kim and Roubini, 2008), or the terms of trade (Monacelli and Perotti, 2010; Enders et al., 2011). In general, the literature on fiscal spillovers is not particularly large; it focuses only on specific country groups and mainly on spending shocks, neglecting the tax side. ${ }^{4}$

Second, our paper is related to the strand of literature analyzing the domestic effects of fiscal policy, specifically for the United States (e.g., Blanchard and Perotti, 2002; Ramey, 2011; Romer and Romer, 2010; Mountford and Uhlig, 2009; Mertens and Ravn, 2013; Ilzetzki et al., 2013). We are closer to those empirical studies using proxy-SVAR methods and the narrative approach as identification scheme, in particular Mertens and Ravn (2013). The latter is one of the papers that develops the proxy-SVAR methodology, together with Stock and Watson (2008); ${ }^{5}$ also, Mertens and Ravn (2013) construct the exogenous narrative tax rate series that we use in the estimation, both for the corporate tax and the personal income tax. They moreover quantify the effects of tax rate shocks, finding large multipliers in the case of personal income tax rate shocks but smaller effects for the corporate tax shock, although they do not provide explicitly an estimate of the corporate tax

\footnotetext{
${ }^{3}$ As also noted in Blagrave et al. (2018), in a standard Mundell-Fleming-Dornbusch framework a fiscal expansion puts upward pressure on interest rates, appreciates the nominal exchange rate, and increases domestic prices.

${ }^{4}$ A set of papers investigate fiscal spillovers within the Euro area, see for instance, Beetsma et al. (2008), Beetsma and Giuliodori (2011) and, more recently, IMF (2017).

${ }^{5}$ Indeed, the methodology of Mertens and Ravn (2013) builds on the precedent work by Stock and Watson (2008) presented in a 2008 NBER summer school, and later applied in Stock and Watson (2012).
} 
multiplier. In our paper we follow the Mertens and Ravn (2013) methodology and we embody it in the GVAR. As in Mertens and Ravn (2013), we also find significant effects on US output of both tax measures; however, our estimates highlight opposite results in terms of relevance of the adopted policy instrument, with the corporate income tax policy being more output enhancing than the personal income tax. This seems to be related to the different sample period of estimate (our sample is thirty years shorter), and to the fact that shocks are unevenly distributed across time: on one side, we miss the big personal income tax shocks of the 1960s and, on the other side, we restrict the analysis to the big corporate income tax shocks of the 1980s and 2000s.

Finally, our paper draws on the GVAR methodology, introduced in the two seminal papers by Pesaran et al. (2004) and Di Mauro et al. (2007). The GVAR framework has been widely used to assess the international transmission of shocks; however, also in the GVAR literature, the topic of fiscal spillovers has been under-investigated. Caporale and Girardi (2013) and Hebous and Zimmermann (2013) study the propagation of non-identified fiscal disturbances originated in the Euro area, while Favero et al. (2011) investigate the effects of contemporaneous fiscal policy shocks at the global level. ${ }^{6}$ None of these studies aims at quantifying the output effect of an identified fiscal shock stemming from the US on the rest of the world. In our paper we aim at filling this gap. The rest of the paper is organized as follows. Section 2 describes the GVAR methodology, the proxy-SVAR methodology and the identification strategy, while Section 3 discusses the data and the specification adopted in the paper, focusing also on the cross-border transmission mechanism of fiscal shocks. Section 4 reports the results obtained. Finally, Section 5 concludes.

\section{Model and identification strategy}

\subsection{The GVAR model}

The GVAR model is a multi-country framework which explicitly allows for interdependencies among countries and markets. The model is particularly useful to investigate the transmission channels of shocks across countries and to quantify the magnitude of such spillovers. The GVAR modeling strategy consists of two steps. In the first step, each country $i$ is modeled separately in a single-country VAR model augmented with exogenous variables (VARX). In each VARX, the endogenous variables are domestic only $\left(X_{i, t}\right)$, while country-specific foreign variables $X_{i, t}^{*}$, constructed as averages of all other

\footnotetext{
${ }^{6}$ Other studies which employ the GVAR methodology to investigate fiscal shocks among Euro area countries are Ricci-Risquete and Ramajo-Hernandez (2015) and Dragomirescu-Gaina and Philippas (2015).
} 
countries' variables, serve as a proxy for common unobserved factors. In this way each country is affected by its domestic developments and by the rest of the world. Each country model is estimated separately, conditional on the foreign variables, in error correction form. In the second step, the country-specific VARX's are stacked together and linked using a matrix of cross country linkages $W$, building in this way the global model.

\section{First step}

Consider $\mathrm{N}+1$ countries, indexed by $i=0,1,2, \ldots N$. Each country is modeled through a $\operatorname{VARX}\left(K_{i}, P_{i}\right)$ of the following form:

$$
X_{i, t}=a_{i, 0}+a_{i, 1} t+\sum_{k=1}^{K_{i}} \phi_{i, k} X_{i, t-k}+\sum_{p=0}^{P_{i}} \Lambda_{i, p} X_{i, t-p}^{*}+u_{i, t}
$$

where $X_{i, t}$ is the vector of country $i^{\prime}$ s domestic variables and $\sum_{k=1}^{K_{i}} \phi_{i, k}$ are the corresponding lagged coefficients; $X_{i, t-p}^{*}$ is the vector of country $i$ 's foreign variables and $\sum_{p=0}^{P} \Lambda_{i, p}$ the associated coefficients; $a_{i, 0}$ and $a_{i, 1}$ are, respectively, the vector of intercepts and the vector of the coefficients of the deterministic time trend. $u_{i, t}$ is the vector of country-specific residuals, which is assumed to be distributed as a white noise process, i.e. $u_{i, t} \sim$ i.i.d. $\left(0, \Sigma_{i}^{u}\right)$. The vector $X_{i, t}^{*}$ plays a crucial role in the GVAR framework and it is defined in the following way:

$$
X_{i, t}^{*}=\sum_{j=0}^{N} w_{i, j} X_{j, t}
$$

where $w_{i, j}$ represents the trade share of country $j$ for country $i$, i.e. the country-specific weight of country $j$ in the total trade of country $i$. Moreover, $w_{i, i}=0$ and $\sum_{j=0}^{N} w_{i, j}=1$. Equation 2.1 can be consistently estimated assuming that $X_{i, t}^{*}$ is weakly exogenous with respect to the other variables in the system. In words, this means that each country is considered as a small open economy with respect to the rest of the world and therefore that Equation 2.1 can be estimated on a country-by-country basis.

Di Mauro et al. (2007) show that Equation 2.1 can be re-written in Error Correction (EC) form, thus allowing for cointegration both within $X_{i, t}$ and between $X_{i, t}$ and $X_{i, t}^{*}$; the model in EC form can be estimated with the Johansen procedure, modified to take into account the exogenous variables (Harbo (1998), Pesaran et al. (2000)). 


\section{Second step}

After the estimation of each country-specific VARX, these are combined and stacked in order to form the global model. For the ease of exposition, we assume that a $\operatorname{VARX}(1,1)$ is estimated for each country:

$$
X_{i, t}=a_{i, 0}+a_{i, 1} t+\phi_{i, 1} X_{i, t-1}+\Lambda_{i, 0} X_{i, t}^{*}+\Lambda_{i, 1} X_{i, t-1}^{*}+u_{i, t}
$$

Defining

$$
z_{i, t}=\left(\begin{array}{l}
X_{i, t} \\
X_{i, t}^{*}
\end{array}\right)
$$

Equation 2.3 can be written as:

$$
A_{i, 0} z_{i, t}=a_{i}+a_{i, 1} t+A_{i, 1} z_{i, t-1}+u_{i, t}
$$

where

$$
A_{i, 0}=\left(I,-\Lambda_{i, 0}\right), A_{i, 1}=\left(\phi_{i, 1}, \Lambda_{i, 1}\right)
$$

The trade weights $w_{i, j}$ are then used to define the link matrix $W_{i}$ and obtain the identity:

$$
z_{i, t}=W_{i} X_{t}
$$

with $X_{t}=\left[X_{0, t}^{\prime}, X_{1, t}^{\prime}, \ldots . X_{N, t}^{\prime}\right]^{\prime}$, i.e. the vector collecting all the country specific endogenous variables of the model. Substituting 2.7 in Equation 2.5, we obtain:

$$
A_{i, 0} W_{i} X_{t}=a_{i, 0}+a_{i, 1} t+A_{i, 1} W_{i} X_{t-1}+u_{i, t}
$$

Now the country-specific models given by Equation 2.8 are stacked to generate the global model for $X_{t}$ :

$$
G_{0} X_{t}=a_{0}+a_{1} t+G_{1} X_{t-1}+u_{t}
$$

where

$$
G_{0}=\left(\begin{array}{c}
A_{00} W_{0} \\
A_{10} W_{1} \\
\vdots \\
A_{N 0} W_{N}
\end{array}\right), G_{1}=\left(\begin{array}{c}
A_{01} W_{0} \\
A_{11} W_{1} \\
\vdots \\
A_{N 1} W_{N}
\end{array}\right)
$$




$$
a_{0}=\left(\begin{array}{c}
a_{00} \\
a_{10} \\
\vdots \\
a_{N 0}
\end{array}\right), a_{1}=\left(\begin{array}{c}
a_{01} \\
a_{11} \\
\vdots \\
a_{N 1}
\end{array}\right), u_{t}=\left(\begin{array}{c}
u_{0 t} \\
a_{1 t} \\
\vdots \\
a_{N t}
\end{array}\right)
$$

With $G_{0}$ non-singular matrix, depending on the trade weights and the estimated parameters, we obtain:

$$
X_{t}=b_{0}+b_{1} t+F_{1} X_{t-1}+v_{t}
$$

where

$$
F_{1}=G_{0}^{-1} G_{1}, \quad b_{0}=G_{0}^{-1} a_{0}, \quad b_{1}=G_{0}^{-1} a_{1}, \quad v_{t}=G_{0}^{-1} u_{t}
$$

Equation 2.10 represents the GVAR model and can be solved recursively. The variancecovariance matrix of the global model is computed directly from the country-specific reduced form residuals $v_{i, t}$ and is represented by the following:

$$
\Sigma_{v}=\left[\begin{array}{cccc}
\Sigma_{v_{0}} & \Sigma_{v_{0}, v_{1}} & \ldots & \Sigma_{v_{0}, v_{N}} \\
\Sigma_{v_{1}, v_{0}} & \Sigma_{v_{1}} & \ldots & \Sigma_{v_{1}, v_{N}} \\
\ldots & \ldots & \ldots & \ldots \\
\Sigma_{v_{N}, v_{0}} & \Sigma_{v_{N}, v_{1}} & \ldots & \Sigma_{v_{N}}
\end{array}\right]
$$

where $\Sigma_{v_{i}, v_{j}}$ is the sample covariance matrix between country $i$ and country $j$ and $\Sigma_{v_{i}}$ is the covariance matrix of country $i$.

\subsection{Identification approach}

In order to identify shocks in the GVAR, one needs to specify a matrix $P_{0}$ that pre-multiplies Equation 2.10 yielding

$$
P_{0} X_{t}=P_{0} b_{0}+P_{0} b_{1} t+P_{0} F_{1} X_{t-1}+\epsilon_{t}
$$

where $P_{0}$ is

$$
P_{0}=\left[\begin{array}{cccc}
P_{0,0} & P_{0,1} & \ldots & P_{0, N} \\
P_{0,1} & P_{1,1} & \ldots & P_{1, N} \\
\ldots & \ldots & \ldots & \ldots \\
P_{N, 0} & P_{N, 1} & \ldots & P_{N, N}
\end{array}\right]
$$

and

$$
\epsilon_{t}=P_{0} v_{t}
$$


is the vector of identified structural shocks, with covariance matrix $\Sigma_{\epsilon}$ :

$$
\Sigma_{\epsilon}=\left[\begin{array}{cccc}
\Sigma_{\epsilon_{0}} & \Sigma_{\epsilon_{0}, v_{1}} & \ldots & \Sigma_{\epsilon_{0}, v_{N}} \\
\Sigma_{v_{1}, \epsilon_{0}} & \Sigma_{v_{1}} & \ldots & \Sigma_{v_{1}, v_{N}} \\
\ldots & \ldots & \ldots & \ldots \\
\Sigma_{v_{N}, \epsilon_{0}} & \Sigma_{v_{N}, v_{1}} & \ldots & \Sigma_{v_{N}}
\end{array}\right]
$$

We are interested in identifying shocks originating from the US only, chosen on $i=$ 0 ; therefore we need to make specific assumptions on $P_{0,0}$ (to identify the US model) and then on the other matrices within $P_{0}$. We take up these issues in the following two paragraphs.

Identifying US fiscal shocks using external instruments. In order to identify fiscal shocks in the US model, we rely on the proxy SVAR methodology. Restrictions on the $P_{0,0}$ matrix are obtained by using proxies for the latent shocks. In each of the two GVAR models we estimate, following Mertens and Ravn (2013), we assume that a narrative measure, denoted by $m_{t}$, is a proxy for the unobserved structural fiscal shock of interest $\epsilon_{f, t}$, with $E\left(m_{t}\right)=0$; in addition, denoting the other non-fiscal US shocks as $\epsilon_{n f, t}$, the methodology assumes that the defined proxy satisfies the following conditions

$$
\begin{array}{r}
E\left[m_{t}, \epsilon_{f, t}\right]=\gamma \neq 0 \\
E\left[m_{t}, \epsilon_{n f, t}\right]=0
\end{array}
$$

In other words, $m_{t}$ is correlated with the unobserved fiscal policy shock of interest and orthogonal with the remaining shocks. Assuming that the fiscal variable is ordered $l^{\text {th }}$ in the US model, the proxy SVAR method provides the restrictions to be placed on the $l^{\text {th }}$ column of the matrix $P_{0,0}$. To obtain those restrictions, one must follow a two-step procedure:

- Run two-stage least squares (2SLS) estimates of all non-fiscal residuals in the US model, $v_{n f, t}$, on the fiscal residual $v_{f, t}$, using each time $m_{t}$ as an instrument for $v_{f, t}$; the estimated coefficients represent each variables' restrictions up to a scale factor;

- Impose covariance restrictions to identify each element in the $l^{\text {th }}$ column of $P_{0,0}$.

Details on the proxy SVAR procedure are reported in Mertens and Ravn (2013). Narrative measures of fiscal policy changes are constructed from historical sources and, as suggested by Mertens and Ravn (2013), they can be viewed as imperfectly correlated 
with linear combinations of the latent structural policy shocks. ${ }^{7}$ In order to validate the use of narrative series as instruments for the latent shocks, one should test the relevance of the proxy by constructing the reliability test statistic of Mertens and Ravn (2013) that is based on the hypothesis of linear random measurement errors. The reliability test statistic represents the fraction of the variance of the measured variable that is explained by the latent variable; it lies between 0 and 1, with large values indicating a high correlation between the proxy and the true underlying tax shock.

Imposing cross-country restrictions. After having imposed restrictions on $P_{0,0}$, we have to impose restrictions on the other elements of $P_{0}$. Provided that we are not interested in identifying shocks in other countries, we assume that all the other matrices on the diagonal of $P_{0}$ are identity matrices. Concerning off-diagonal matrices, we impose all cross-country correlations between model residuals to be zero. Indeed, correlations between the residuals of the GVAR may occur both within countries (i.e. among variables of a country-specific model) but also across countries (i.e. among variables in different countries). While the first type of correlations is taken care of through the identification procedure described in the previous paragraph, residuals can still be contemporaneously correlated across countries, creating concerns about reverse spillover effects. Although, having conditioned domestic models on foreign variables, cross-country correlations are generally very small, the case of significant correlations with specific foreign variables can not be ruled out, giving rise to possible identification issues. Given the central role of the US economy, it is reasonable to assume that it does not react within the quarter to foreign developments. This restriction is crucial to complete identification in GVAR models, although it is not always stressed in the GVAR literature.

By imposing such correlations to be zero, we obtain a block-diagonal $P_{0}$ matrix. Therefore, the resulting $P_{0}$ matrix is

$$
P_{0}=\left[\begin{array}{ccccc}
P_{0,0} & 0 & 0 & \ldots & 0 \\
0 & I & 0 & \ldots & 0 \\
\ldots & \ldots & \ldots & \ldots & \ldots \\
0 & 0 & 0 & \ldots & I
\end{array}\right]
$$

\footnotetext{
${ }^{7}$ Indeed, measurement errors may arise both from the fact that historical records sometimes contradict each other, and because narrative series typically disregard minor policy changes that are censored to zero.
} 


\subsection{Impulse response functions}

For the dynamic analysis of shocks, the GVAR literature largely relies on Generalized Impulse Response Functions (GIRFs) (Koop et al. (1996) and Pesaran and Shin (1997)), that in our case take the form of Structural GIRFs (SGIRFs) as our model is identified. The response of variable $j$ at time $t+n$ to a one standard error shock at time $t$ given to variable $l$ is given by the $j^{\text {th }}$ element of:

$$
\operatorname{SGIRF}\left(x_{t} ; \epsilon_{l t}, n\right)=\frac{\epsilon_{j}^{\prime} A_{n}\left(P_{0} G_{0}\right)^{-1} \Sigma_{\epsilon} e_{l}}{\sqrt{e_{l}^{\prime} \Sigma_{\epsilon} e_{l}}}
$$

where $e_{l}=(0 ; 0 ; \ldots ; 0 ; 1 ; 0 ; \ldots ; 0)$ is a selection vector with unity as the $l^{\text {th }}$ element; $G_{0}$ is defined as in Equation 2.9; $A_{n}$ is

$$
A_{n}=\sum_{i=1}^{p} F_{i} A_{n-i}, \quad A_{0}=I, \quad n=1 \ldots p
$$

\section{Data and transmission channels}

We specify two GVAR models using quarterly data. Each model encompasses 25 economyspecific VARX models, where the included economies account for about 90 percent of world GDP. ${ }^{8}$ Subject to data availability, we consider the same set of variables for each economy except for the US. For non-US economies, domestic variables are real GDP $y_{i, t}$ consumer price inflation $\pi_{i, t}$, real exchange rate $r_{i, t}$ (defined as the nominal exchange rate $e_{i, t}$ minus domestic CPI, following Di Mauro et al., 2007), the 3-month interest rate $i_{i, t}^{\text {s }}$ the 10-year government bond yield $i_{i, t}^{l}$, the real equity price index $q_{i, t}$ (the equity index deflated by domestic CPI) and real exports of goods and services $\exp _{i, t}{ }^{910}$ Foreign variables, constructed as trade-weighted averages of variables in all other economies, are the following: foreign real GDP $y_{i, t}^{*}$, foreign consumer price inflation $\pi_{i, t}^{*}$, foreign real equity price $q_{i, t}^{*}$ and the foreign 3-month short-rate $i_{i, t}^{i *}$. The real exchange rate is not included in the set of foreign variables of non-US models to avoid multicollinearity.

\footnotetext{
${ }^{8}$ The countries included are Argentina, Australia, Brazil, Canada, China, Chile, Euro Area, India, Indonesia, Japan, Korea, Mexico, Norway, New Zealand, Peru, Philippines, South Africa, Saudi Arabia, Singapore, Sweden, Switzerland, Thailand, Turkey, United Kingdom and USA. The Euro area is constructed as the aggregation of eight countries: Austria, Belgium, Finland, France, Germany, Italy, Netherlands, Spain.

${ }^{9}$ All variables except the 3-month and 10-year rates are set equal to 100 in 2000Q1 and expressed in natural logarithms.

${ }^{10}$ The nominal exchange rate $e_{i, t}$ is defined as the exchange rate vis-à-vis the US dollar. For this reason, the real exchange rate is not included in the US model, as $e_{U S, t}=1$ for all $t$.
} 
Table 1: Summary of the variables included in the GVAR.

\begin{tabular}{|c|c|c|c|c|}
\hline & "Non-US model & & $\overline{\text { US model }}$ & \\
\hline & Domestic & Foreign & Domestic & Foreign \\
\hline All GVARs: & $\begin{array}{c}y_{i} \\
\pi_{i} \\
r_{i} \\
i_{i}^{s} \\
i_{i}^{l} \\
q_{i} \\
\exp _{i}\end{array}$ & $\begin{array}{c}y_{i}^{*} \\
\pi_{i}^{*} \\
- \\
i_{i}^{S *} \\
- \\
q_{i}^{*} \\
-\end{array}$ & $\begin{array}{c}y_{U S} \\
\pi_{U S} \\
- \\
i_{U S}^{S} \\
i_{U S}^{l} \\
q_{U S} \\
-\end{array}$ & $\begin{array}{c}y_{U S}^{*} \\
\pi_{U S}^{*} \\
r_{U S}^{*} \\
i_{U S}^{S *} \\
i_{U S}^{l *} \\
q_{U S}^{*} \\
-\end{array}$ \\
\hline GVAR 1: & $\begin{array}{l}- \\
- \\
-\end{array}$ & $\begin{array}{l}- \\
- \\
-\end{array}$ & $\begin{array}{l}\text { pitrus }_{U S} \\
\text { pitb }_{U S} \\
\text { gcgi }_{U S}\end{array}$ & $\begin{array}{l}- \\
- \\
-\end{array}$ \\
\hline GVAR 2: & $\begin{array}{l}- \\
- \\
-\end{array}$ & $\begin{array}{l}- \\
- \\
-\end{array}$ & $\begin{array}{l}\operatorname{citr}_{U S} \\
\text { citb }_{U S} \\
\operatorname{gcg} i_{U S}\end{array}$ & $\begin{array}{l}- \\
- \\
-\end{array}$ \\
\hline
\end{tabular}

Table 1 reports the variables included in the non-US models (for each country $i$ ) and in the US model. Variables are: real GDP $y_{i}$, consumer price inflation $\pi_{i}$, real exchange rate $r_{i}$ (defined as the nominal exchange rate $e_{i}$ minus domestic CPI), the 3-month interest rate $i_{i}^{\text {s }}$, the 10-year government bond yield $i_{i}^{l}$, the real equity price index $q_{i}$ (the equity index deflated by domestic CPI), real exports of goods and services expi. gcgi $i_{U S}$ is government spending, taxrev $v_{U}$ are net tax revenues, pitr $_{U S}$ ( citr $_{U S}$ ) is personal (corporate) income tax rate and pitb $b_{U S}$ (citb $b_{U S}$ ) is personal (corporate) income tax base. 
The US model is slightly different for a number of reasons. First, as our aim is to study the effect of a fiscal policy expansion in the US on the rest of the world, we include, as domestic variables, US fiscal variables, both on the spending and on the tax side. Government spending and tax variables are constructed following previous works on US fiscal shocks (Blanchard and Perotti (2002) and Mertens and Ravn (2013), among others). On the spending side, we include real government expenditure to take into account the possible reaction of spending variables following the tax shock; on the tax side, we include the average personal income and corporate tax rates, together with their respective tax bases (net of transfers and interest payments). ${ }^{11}$ Second, we do not include US exports among the domestic variables in the US, in order to reduce the number of parameters to be estimated and make the identification as neat as possible. Concerning the instruments for personal and corporate tax rate shocks, we rely on the legislated tax liability changes categorized by Mertens and Ravn (2013) from the total tax liabilities changes recorded by Romer and Romer (2010). Our tax models feature also personal and corporate income tax bases in order to be able to calculate fiscal multipliers, and general government spending to control for the endogenous response of fiscal policy. Regarding US foreign variables, we included, besides the same variables as in the non-US models, the real exchange rate, following Di Mauro et al. (2007). This implies that also the US is considered as a small open economy. ${ }^{12}$ Table 1 summarizes the domestic and foreign variables included in the US and non-US models.

We estimate two GVARs, one to study the effects of personal income tax shocks and one for corporate income tax shoks:

- In GVAR \#1, the US model is augmented with the personal income tax rate, the personal income tax base and government expenditure;

- In GVAR \#2, the US model is augmented with the corporate income tax rate, the corporate income tax base and government expenditure;

The GVAR models are estimated over the period 1979 Q2 - 2006 Q4 because of data availability issues: observations before 1979 Q2 are not available for all countries, while the available tax instruments data end in 2006 Q4. Appendix A.1 and A.2 contain more details regarding the specification chosen and the data sources.

\footnotetext{
${ }^{11}$ We do not include fiscal variables in non-US models because series of government spending and taxes are not available on a quarterly frequency for all countries; for countries in which series are available, we choose not to increase model size further.

${ }^{12}$ While the small open economy assumption may sound implausible in the case of the US, weak exogeneity requires that foreign variables are independent only with respect to the long-run parameters of the model, as Di Mauro et al. (2007) discuss and test formally. Results of such test, confirmed for our sample, are available upon request.
} 


\subsection{Transmission channels}

Before describing the results of the paper, it is useful to summarize the main transmission channels through which fiscal policy shocks in the US may affect real variables in the rest of the world. The first channel operates through trade, in particular through the so-called expenditure boosting effect. Following a fiscal expansion that increases US output, US demand for imports increases as well, to an extent depending on the marginal propensity to import, both of the public and of the private sector. Output in foreign countries can thus rise through higher export demand. This direct channel can be reinforced via third-party effects, i.e through the aforementioned mechanism working in all the foreign countries experiencing a boost in output. The second channel is represented by the real exchange rate. The US fiscal expansion is expected to increase domestic interest rates and to appreciate the US dollar, improving price competitiveness for all goods and services produced abroad and stimulating foreign exports and output (expenditure switching effect).

A fiscal shock can also impact foreign GDP through the financial channel. A loose fiscal policy stance in the US affects domestic interest rates, which in turn can impact foreign financial variables through financial linkages. The direction in which variables can be affected is not straightforward. On the one hand, in a standard portfolio balance model, the financial channel should cause both domestic and foreign interest rates to rise, putting a drag on the magnitude of spillovers on foreign output. On the other hand, an expansionary fiscal policy in the US might generate the opposite effect, putting downward pressure on domestic and foreign interest rates. Faccini et al. (2016) and Corsetti and Muller (2013) obtain falling interest rates by making the assumption of a subsequent reversal of the fiscal shock; alternative explanations suggest that lower taxes may either expand aggregate supply or increase firms' savings more than investments, in both cases putting downward pressures on prices and interest rates. Fiscal spillovers might also be transmitted by an equity price channel: expected profits of foreign exporting firms may rise and, depending on whether there is no offset from discount rates (which rise due to foreign central bank reactions), they put upward pressure on equity prices. This produces wealth effects for portfolio investors that could support consumption and investment.

Overall, the magnitude of fiscal spillovers is an empirical question. The relative importance of the aforementioned channels depends on the strength of trade and financial linkages among the source and recipient countries, and to a smaller extent, among recipient countries themselves. Finally, it might also depend on the composition of the fiscal shock, i.e. whether the fiscal expansion is implemented through spending increases or tax reductions, and also on the particular type of spending or tax instrument. 


\section{Results}

In this section we describe our main results. In order to compare the effects of the two shocks, we comment on the results of the two GVAR models together, divided between domestic and spillovers effects; then, we construct domestic and international fiscal multipliers. The shocks of interest are: shock to average personal income tax rate (PITR henceforth) and shock to corporate income tax rate (CITR henceforth). Last, we discuss the main transmission channels.

Realiability tests ensure the relevance of the chosen tax instruments in our settings. In GVAR \#1, the reliability test on the adopted instrument shows a statistic of 0.9 , and in GVAR \#2, of 0.8. These values are in the good-quality range for tax models reported in Mertens and Ravn (2013) and Mertens and Ravn (2014), validating the adopted identification procedures. Impulse response functions (IRFs), standardized to obtain comparable results, are shown in Figures 4.1 to 4.8. Regarding their interpretation, we highlight the following points. First of all, all impulse responses can be interpreted as percentage point reactions to a shock of -1 percentage point size in the tax rate. Second, the impulse response functions show a permanent behavior, both for the shocked and the response variables. Such behavior is driven by the fact that the model is estimated in error correction form and, therefore, takes into account the existing cointegrating relationships among variables, as outlined in Section 2. Finally, the IRFs display the median estimates along one standard deviation confidence bands, calculated through the bootstrap procedure. ${ }^{13} 14$

\subsection{Domestic effects}

Figure 4.1 displays the response of US real GDP to a -1 p.p. shock to US PITR and CITR. In both cases, the output response is positive and significant, showing a persistent behaviour, similar to that of the shocked variable, i.e. the tax rate. The timing of the response is slightly different across the two shocks, with GDP increasing on impact following the PITR shock, while reacting with a lag to the CITR shocks. Short and long-term interest

${ }^{13}$ In order to bootstrap the GVAR model as in 2.10 we need to resample the estimated residuals, to obtain:

$$
X_{t}^{\text {boot }}=\hat{b}_{0}+\hat{b}_{1} t+\hat{F}_{1} X_{t-1}+v_{t}^{\text {boot }}
$$

The resampling procedure is carried out by making random draws with replacement from the residual vector $\left[\hat{v}_{1}, \hat{v}_{1}, \ldots, \hat{v}_{T},\right]$, and impulse responses are recomputed at each draw.

${ }^{14}$ We adopt one standard deviation confidence bands as uncertainty surrounding international spillover effects is considered higher than that around domestic effects. Other papers in the GVAR literature adopting one-standard deviation bands are, for example, Caporale and Girardi (2013) and Inoue et al. (2015). 
rates react significantly, increasing in response to the personal income tax shock while they fall after the corporate tax shock.

In order to compare the quantitative effect of the two different shocks, we report the results in terms of their implied multipliers, i.e. the dollar increase in GDP following a one dollar decrease in tax revenues, see Table 4.1. ${ }^{15}$ One year after the shock, both tax rate shocks yield multipliers greater than one, with the one related to the personal income tax equal to 1.1 and the multiplier related to the corporate income tax equal to 2.5; five years after the shock, tax multipliers reach high levels in case of a corporate income tax shock (4.8) while remain close to 1 in case of personal tax rate shock. The high value of the corporate tax multiplier partly relates to the negative response of the long-term interest rate, which reinforces the effect of fiscal policy on output. Such result is in line with tax multipliers reported in Mountford and Uhlig (2009). As discussed in the Literature review Section, the stronger output effect of the corporate tax rate shock with respect to the personal income tax rate shock can be ascribed to the higher relevance of surprises in the corporate tax rate in the post-80s sample.

\begin{tabular}{lccc}
\hline \hline & Impact & 1-year & 5-year \\
\hline \hline Personal income tax rate (PITR) & 0.4 & 1.1 & 1.4 \\
Corporate income tax rate (CITR) & n.s. & 2.5 & 4.8 \\
\hline
\end{tabular}

Table 4.1 reports fiscal multipliers for the United States in case of negative PITR and CITR shocks. GDP elasticities are scaled by average GDP ratios over the 1979-2006 sample. All reported multipliers are significant; n.s. stands for not significant.

\subsection{Spillover effects}

Tax rate shocks have positive and statistically significant, albeit relatively small, international output spillovers. For the sake of brevity, we focus on the main economic partners of the United States, i.e. the Euro area, China, Japan, the United Kingdom and Canada, for which we detail the main transmission channels; for other emerging economies, we only discuss the overall effect of shocks on economic growth.

\footnotetext{
${ }^{15}$ The response of tax revenues $t$ periods after the shock $(t=0, \ldots, n)$ is constructed by combining the dynamics of the shock with the response of the tax base, following Mertens and Ravn (2013)

$$
\hat{t r}_{t}=\hat{T}_{t}^{i} / \bar{T}^{i}+\hat{b}_{t}^{i}
$$

where $T$ is the tax rate of type $i=\operatorname{PITR}, C I T R, \bar{T}^{i}$ is the mean average tax rate and $b$ is the appropriate tax base; hats denote impulse responses and lower case letters denote logged variables.
} 

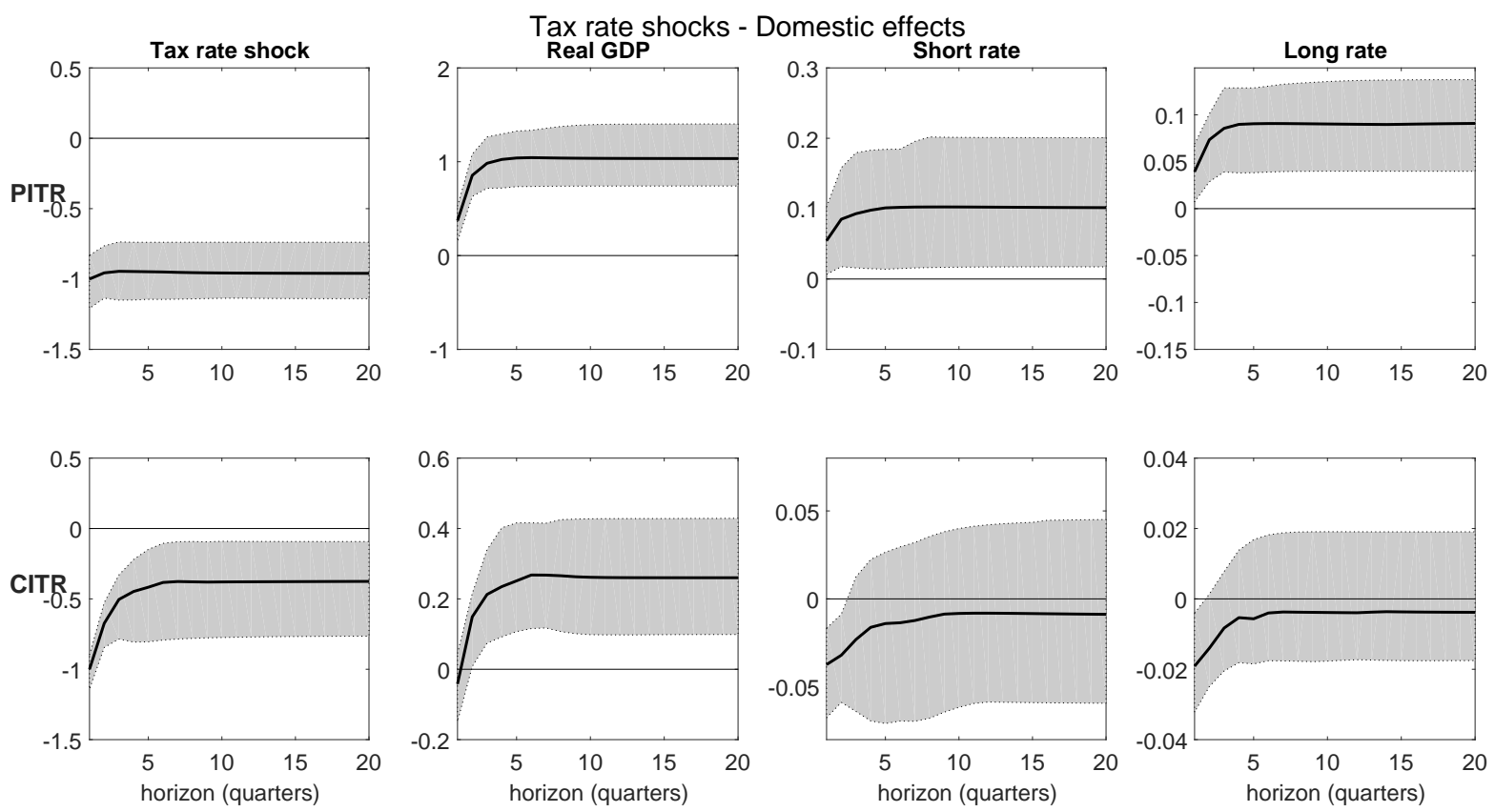

Figure 4.1: US tax rate shocks, domestic effects. Impulse responses from a -1 percentage point shock to US Personal income tax rate (PITR) and to US Corporate income tax rate (CITR). Bootstrap median estimates with $68 \%$ confidence bands.

Effects on GDP International spillovers are reported in Figures 4.2 to 4.4. Output spillovers are significant in most of the main advanced economies. In particular, they are strongest in Canada and of comparable size in the Euro area, China, Japan and the United Kingdom. The shapes of foreign GDP responses follow those of US GDP: spillovers from PITR shocks are front-loaded while those from CITR shocks are more gradual. Concerning the differences between the effects among tax shocks, spillovers from personal tax shocks have tighter confidence bands. The effect of fiscal policy on emerging countries is on average less significant than that on advanced economies (Figure 4.4). Among EMEs, they are stronger in Mexico and South East Asiathan in Latin America, and never significant in India. ${ }^{16}$

International fiscal multipliers Tables 2, 3 and 4 quantify the effect of fiscal shocks on GDP in recipient economies in terms of fiscal multipliers. International fiscal multipliers are here defined as the dollar increase in foreign GDP following a one dollar decrease in US tax revenues. The fiscal multiplier of country $i, M^{i}$, observed $t$ periods after the shock

\footnotetext{
${ }^{16}$ South East Asia is the GDP-weighted aggregation of Indonesia, Philippines and Thailand, while Latin America is the aggregation of Argentina, Brazil, Chile and Peru.
} 

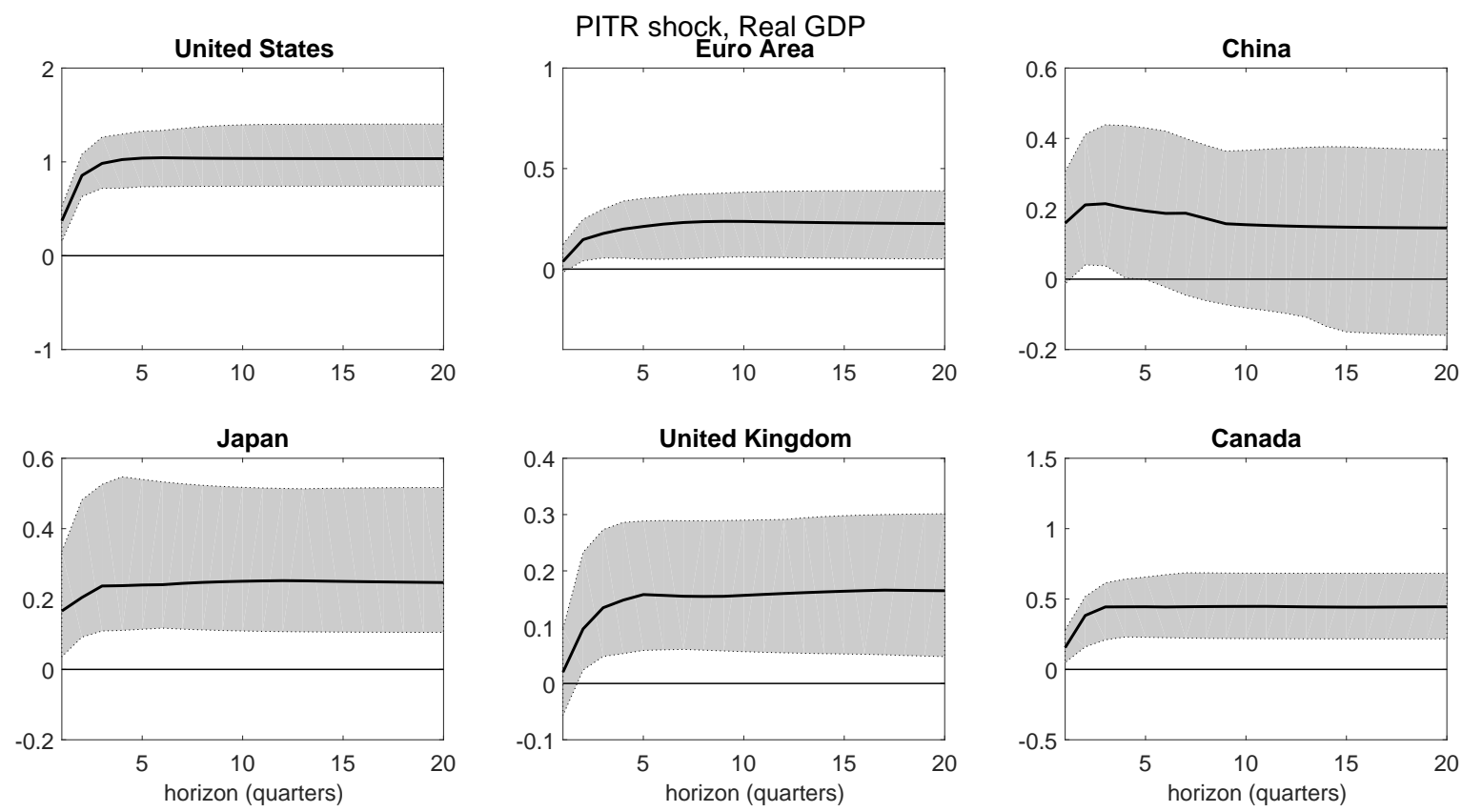

Figure 4.2: Personal tax rate shock, spillover effects. Impulse responses of real GDP rate from a -1 percentage point shock to US Personal income tax rate (PITR). Bootstrap median estimates with $68 \%$ confidence bands.
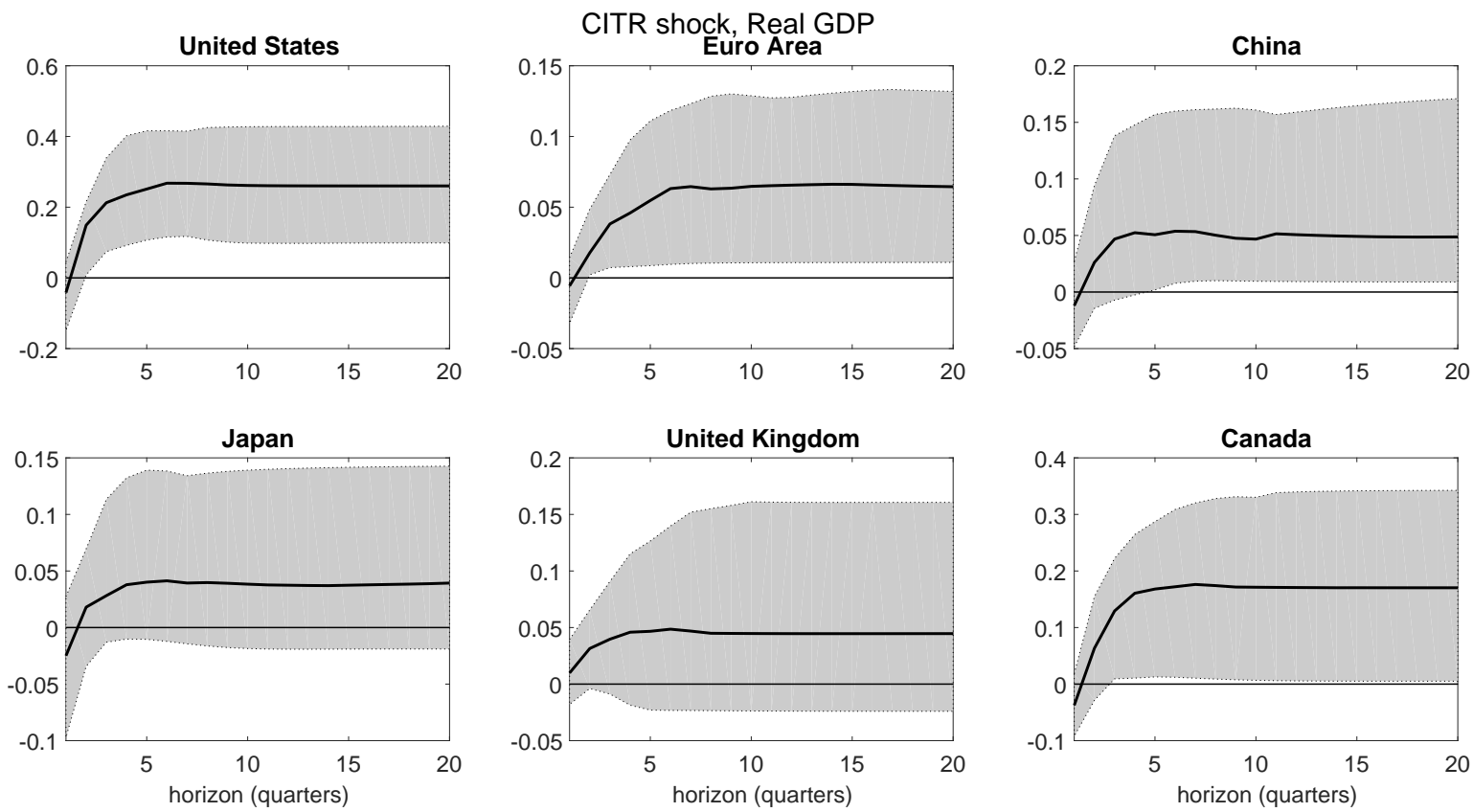

Figure 4.3: Corporate tax rate shock, spillover effects. Impulse responses of real GDP rate from a 1 percentage point shock to US Corporate income tax rate (CITR). Bootstrap median estimates with $68 \%$ confidence bands. 

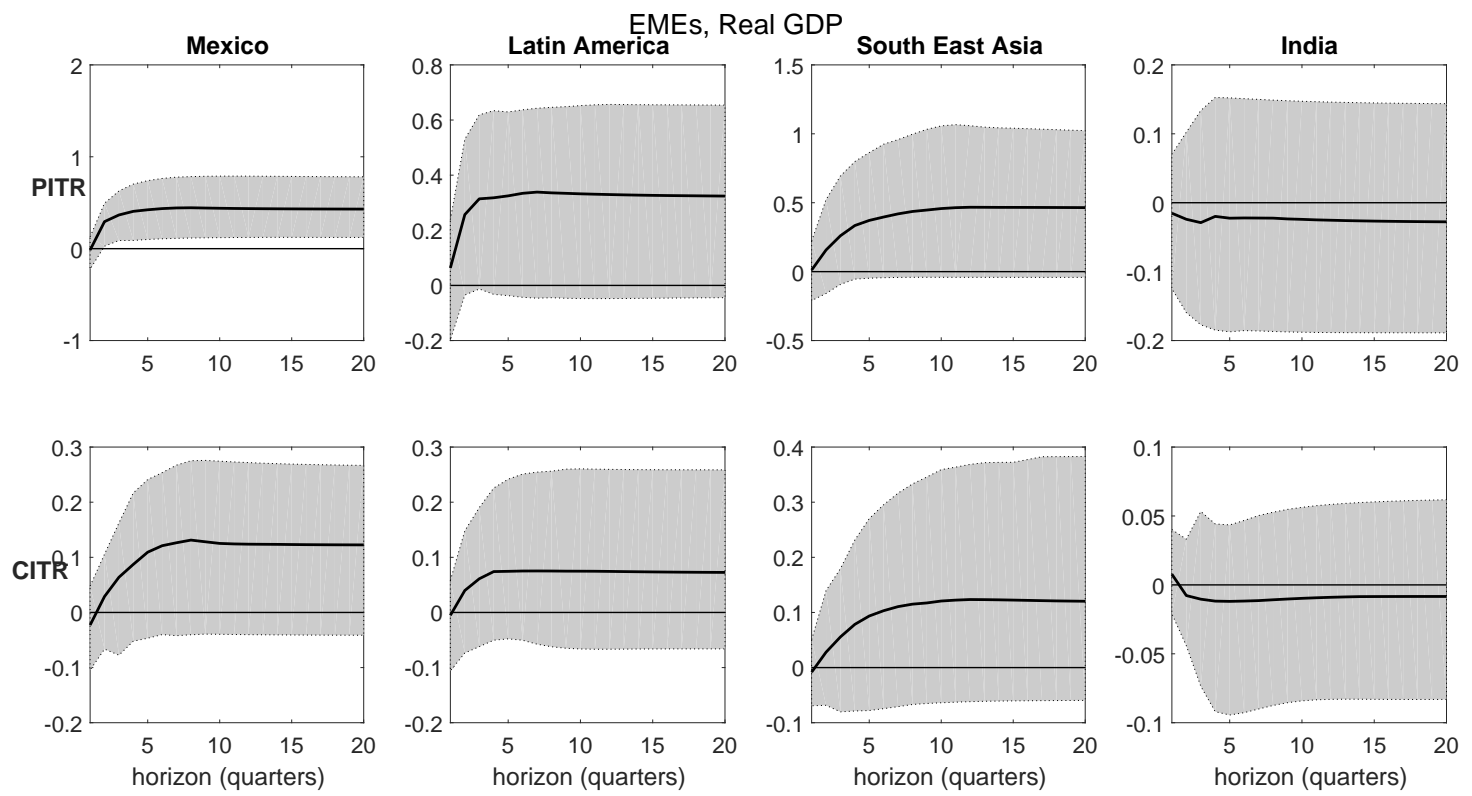

Figure 4.4: Spillovers to EMEs. Impulse responses of real GDP from a -1 p.p. shock to US Personal income tax rate (PITR) and US Corporate income tax rate (CITR). Latin America is the GDP-weighted aggregation of Argentina, Brazil, Chile and Peru. South East Asia is the GDP-weighted aggregation of Indonesia, Philippines and Thailand. Bootstrap median estimates with $68 \%$ confidence bands.

$(t=0, \ldots, N)$ and referred to a US fiscal instrument $F I^{u s}$, is given by the following:

$$
M_{F I, t}^{i}=\frac{\Delta Y_{t}^{i}}{\Delta F I_{t}^{u s}}
$$

$\Delta F I^{u s}$ is the response of the fiscal instrument and $\Delta Y^{i}$ that of GDP in country $i .{ }^{17}$ Empirically, international multipliers are computed as follows. Defining the elasticity of GDP to the fiscal instrument at period $t$ as the ratio of the impulse response of GDP over that of the fiscal instrument, i.e.

$$
\epsilon_{F I, t}^{i}=\frac{\Delta Y_{t}^{i}}{Y_{t}^{i}} / \frac{\Delta F I_{t}^{u s}}{F I_{t}^{u s}},
$$

fiscal multipliers are obtained by weighting the elasticities by the ratio of the fiscal instrument to real GDP at some point in time

$$
M_{F I, t}^{i}=\epsilon_{F I, t}^{i} \frac{F I^{u s}}{Y^{i}}
$$

\footnotetext{
${ }^{17}$ The fiscal instrument is the tax revenue, obtained by combining the tax rate shock and the response of tax base as detailed in footnote 15 .
} 
Following Ramey (2016), we report cumulated multipliers given by

$$
M_{F I, t}^{i}=\frac{\sum_{s=0}^{t} \Delta Y_{s}^{i}}{\sum_{s=0}^{t} \Delta F I_{s}^{u s}}
$$

In order to compute international multipliers, we calculate the ratio FI/Y in Equation 4.4 as the average FI/Y ratios throughout the estimation period for each economy. ${ }^{18}$

The tables below summarize the estimates of the international fiscal multipliers for the two types of tax rate shocks: impact multipliers (Table 2), one-year and five-year mulitpliers (Tables 3 and 4). In general, international fiscal multipliers are small, ranging between 0 and 0.3. On the five year horizon, they are highest for the corporate tax shock. There is variation across countries: multipliers are basically null in China and strongest in Canada and Japan. The aforementioned results suggest that US fiscal policy does affect economic activity in foreign economies, but its impact is limited.

Table 2: International fiscal multipliers, impact.

\begin{tabular}{lccccc}
\hline & Euro area & China & Japan & UK & Canada \\
\hline \hline Personal income tax rate (PITR) & 0 & 0 & 0 & 0 & 0 \\
Corporate income tax rate (CITR) & 0 & 0.1 & 0.1 & 0 & 0 \\
\hline
\end{tabular}

Table 2 reports the fiscal multipliers for the subcategories of tax revenues, for the Euro area, China, Japan, UK and Canada. All reported multipliers are statistically significant; values equal to zero indicate multipliers between 0 and 0.1 .

Table 3: International fiscal multipliers, one year after the shock.

\begin{tabular}{lccccc}
\hline \hline & Euro area & China & Japan & UK & Canada \\
\hline \hline Personal income tax rate (PITR) & 0 & 0 & 0 & 0 & 0.1 \\
Corporate income tax rate (CITR) & 0.1 & 0.1 & 0.1 & 0.1 & 0.2 \\
\hline
\end{tabular}

Table 3 reports the fiscal multipliers for the subcategories of tax revenues, for the Euro area, China, Japan, UK and Canada. All reported multipliers are statistically significant; values equal to zero indicate multipliers between 0 and 0.1 .

\footnotetext{
${ }^{18}$ This procedure can lead to a bias when significant trends in this ratio are present (Ramey, 2016). We also computed the ratio using end-of-sample values and multipliers do not change significantly.
} 
Table 4: International fiscal multipliers, five years after the shock.

\begin{tabular}{lccccc}
\hline \hline & Euro area & China & Japan & UK & Canada \\
\hline \hline Personal income tax rate (PITR) & 0.1 & 0 & 0 & 0 & 0.1 \\
Corporate income tax rate (CITR) & 0.2 & 0.1 & 0.3 & 0.1 & 0.3 \\
\hline
\end{tabular}

Table 4 reports the fiscal multipliers five years after the shock for the subcategories of tax revenues, for the Euro area, China, Japan, UK and Canada. All reported multipliers are statistically significant; values equal to zero indicate multipliers between 0 and 0.1 .

Transmission channels Figures 4.5 to 4.8 document the international transmission channels of the US fiscal shocks. The trade channel appears to be the dominant propagation mechanism. This result is partly driven by the fact that, in the model, international financial markets are also linked by trade weights, so the pure financial spillovers from the US to the rest of the world may be underestimated. However, other estimates we made with our GVAR, assigning higher weights to US financial variables in foreign economies confirm the dominance of the trade channel. ${ }^{19}$ Two different mechanisms lie behind the trade channel, i.e. the expenditure switching and the expenditure boosting effects, and affect the various economies in different ways. As Figure 4.5 shows, following a personal income tax cut in the United States, real exchange rates vis-à-vis the US dollar depreciate for the Euro Area, and the United Kingdom, making their exports cheaper: these countries benefit from an expenditure switching effect. This result is consistent with the main prediction of standard theoretical models, including both the Mundell-Fleming-Dornbush (MFD) model and open macro DSGEs. However, at least for what concerns spending shocks such theoretical result has been challenged by a number of empirical papers, like Kim and Roubini (2008), Ravn et al. (2012), Kim (2015), Corsetti et al. (2012b) and Ilzetzki et al. (2013). ${ }^{20}$ This body of literature documents that an increase in government consumption leads to a depreciation of the real exchange rate and in some cases, also to a contemporaneous deterioration of the current account balance. While we do not consider spending shocks in our framework, we document that such puzzle regarding the

\footnotetext{
${ }^{19}$ In order to simulate a fully direct financial spillover, in a robustness analysis we assume that US shortterm rates, long-term rates and equity prices enter the VARXs of foreign countries with unitary weights. We simulate a new GVAR with mixture of trade and unitary weights for PITR shocks, for which a stronger, positive reaction of foreign interest rates could, in principle, mute the positive trade effects on foreign output. Estimates, available upon request, show that spillovers are still positive, confirming the dominance of the trade channel on the financial channel.

${ }^{20}$ One notable exception in this literature is Forni and Gambetti (2016), which shows that government spending news shocks appreciate the real exchange rate, instead of depreciating. However, it is important to highlight that the authors focus on news shocks and not on the standard surprise shock.
} 
response of the real exchange rate is less evident for tax rate shocks.

Figure 4.6 reports the response of real exports. Exports rise even in cases where the real exchange rate does not depreciate, as for Japan, Canada and China. ${ }^{21}$ Indeed, notwithstanding the behavior of the real exchange rate, exports receive a boost from the stronger import demand in the US, suggesting the presence of a powerful expenditure boosting mechanism.

An important transmission mechanism is also represented by financial channels. Such channels point to the response of long-term interest rates and equity prices as vehicles for the transmission of fiscal shocks abroad, as explained in Section 3. Overall, the effect of financial channels on growth is ambiguous. As regards long-term rates, in most cases they increase following the US shocks while only in few cases they fall. Indeed, in the United States, long-term interest rates increase in the case of PITR shocks, putting a drag on economic activity both domestically and abroad. In the case of a CITR shock, they are generally much less significant and, in some cases, they fall on impact reinforcing the expansionary effects of trade. Possibly, the response of interest rates abroad depends on the balance between foreign monetary policy reactions and expectations of a policy reversal in the United States, acting as a drag on economic growth in the first case and stimulating investment and consumption in the second one.

Finally, Figure 4.8 reports impulse responses of stock prices, which are a possible source of wealth effects. In the case of PITR shocks, the response is significant, but has negative sign: domestic and foreign stock prices fall, meaning that the increase in interest rates (highly elastic to PITR shocks) prevails on the rise in firms' expected profits, producing a negative wealth effect. In case of CITR shocks, the effects are not significant, suggesting that stock prices do not play a key role in the transmission of US corporate tax shocks across the board.

\footnotetext{
${ }^{21}$ The real exchange rate is not significant in China and, for the corporate tax shock, works in the opposite direction for Canada.
} 

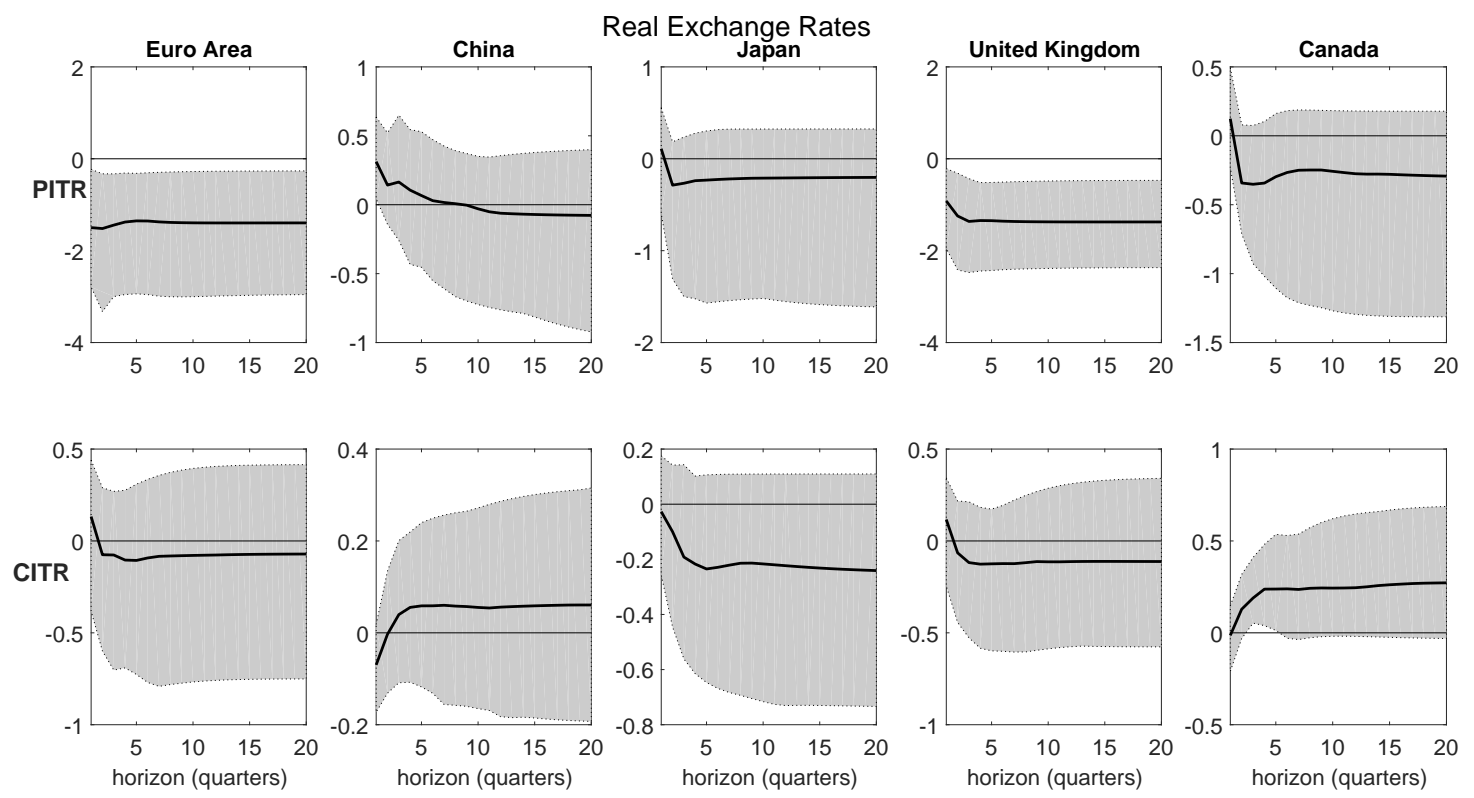

Figure 4.5: Trade channel - exchange rates. Impulse responses of real foreign exchange rate from a 1 percentage point (p.p.) shock to a -1 p.p. shock to US Personal income tax rate (PITR) and US Corporate income tax rate (CITR). Values above zero mean appreciation of foreign currencies towards the US dollar. Bootstrap median estimates with $68 \%$ confidence bands.
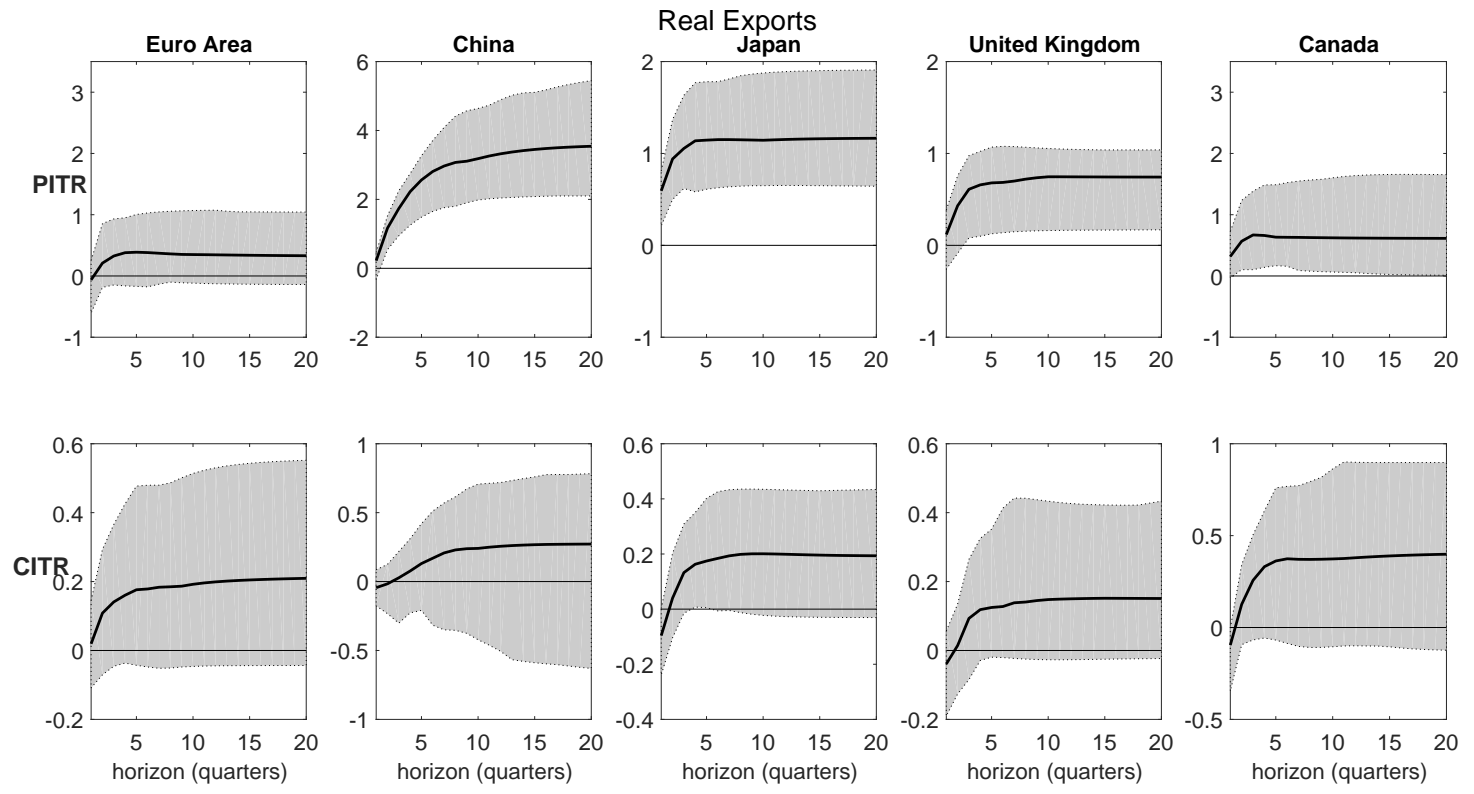

Figure 4.6: Trade channel - real exports. Impulse responses of real exports from a 1 percentage point (p.p.) shock to a -1 p.p. shock to US Personal income tax rate (PITR) and US Corporate income tax rate (CITR). Bootstrap median estimates with $68 \%$ confidence bands. 

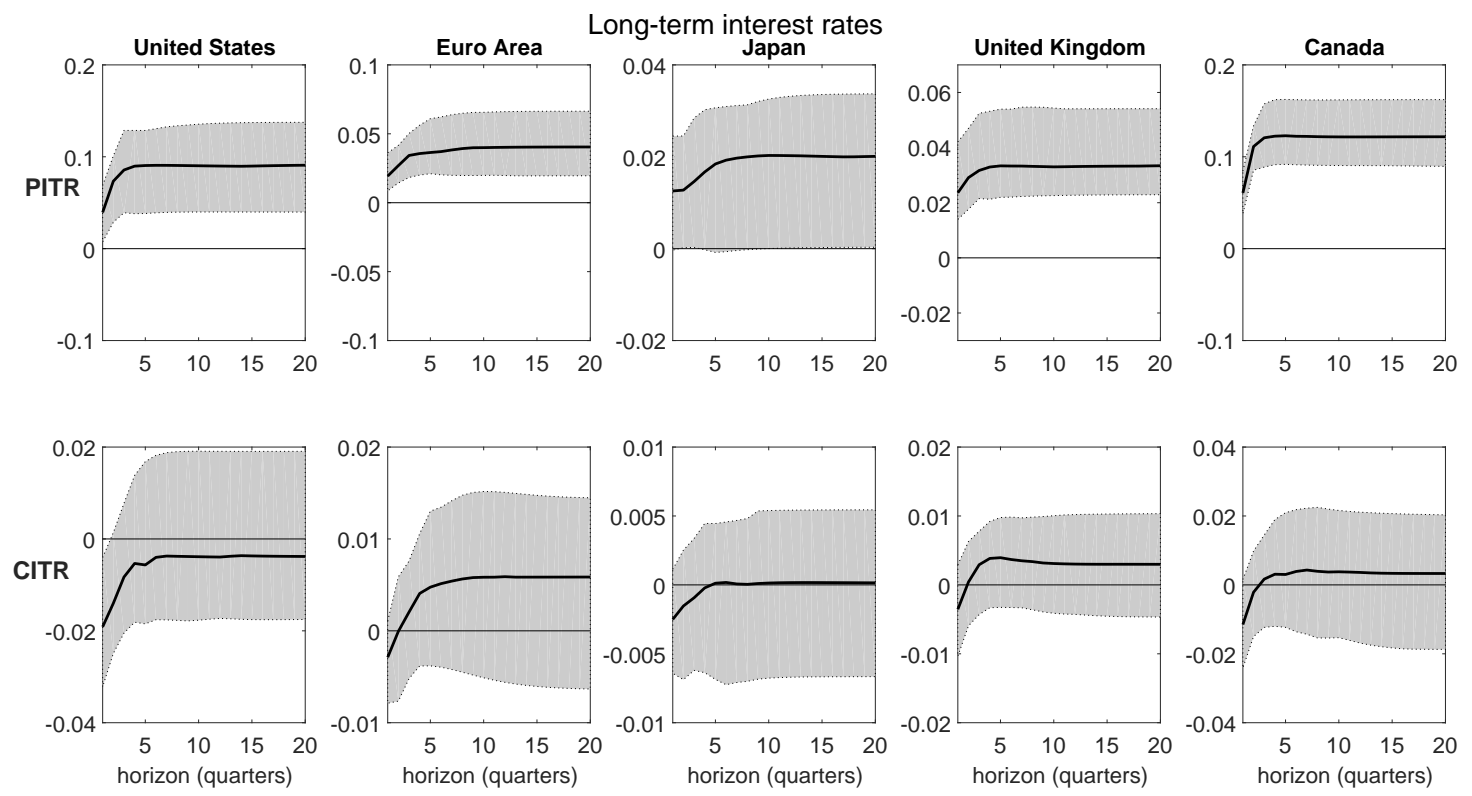

Figure 4.7: Financial channel - long rates. Impulse responses of nominal long-term interest rates from a 1 percentage point (p.p.) shock to a -1 p.p. shock to US Personal income tax rate (PITR) and US Corporate income tax rate (CITR). Bootstrap median estimates with $68 \%$ confidence bands.
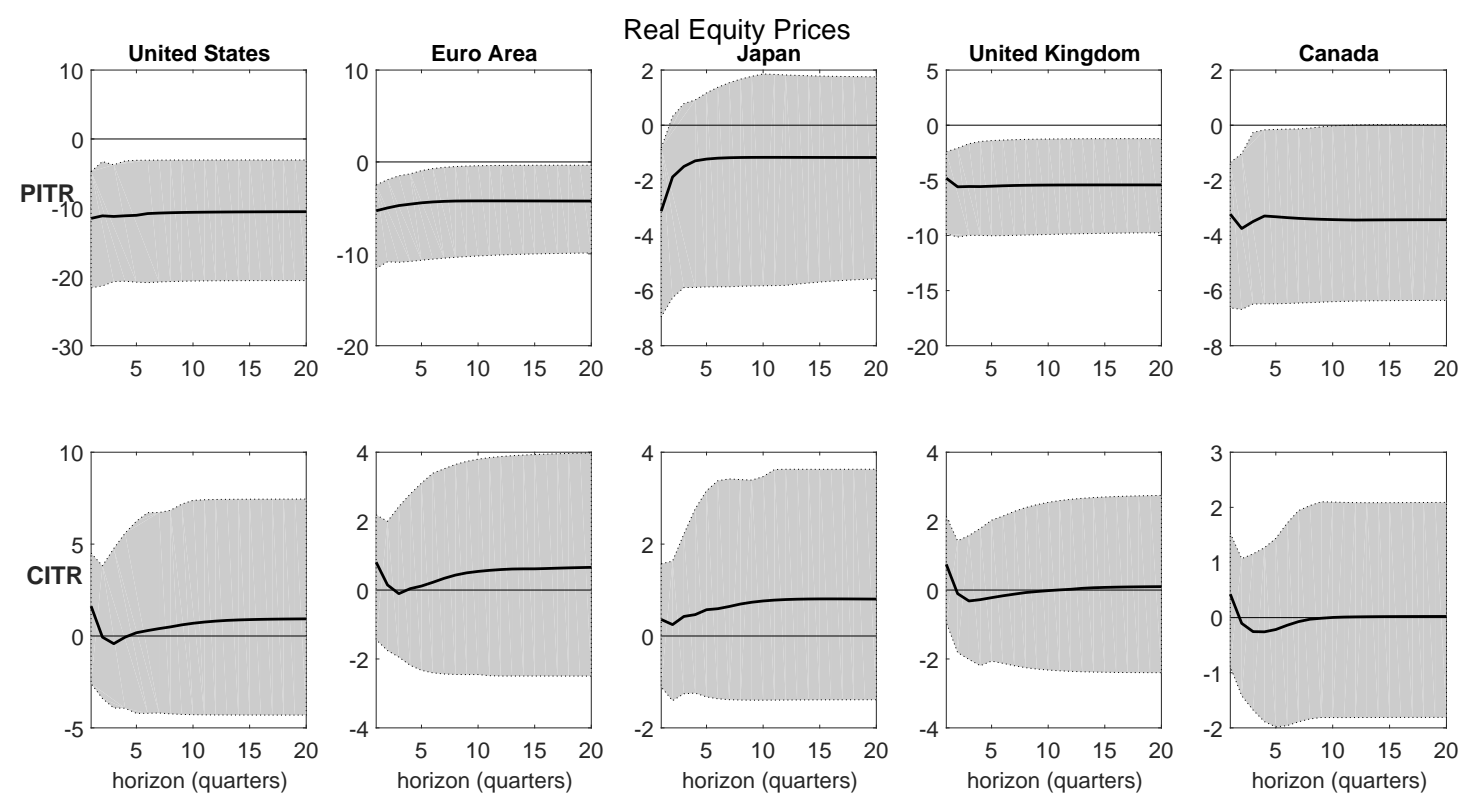

Figure 4.8: Financial channel - equity prices. Impulse responses of real equity prices from a 1 percentage point (p.p.) shock to a -1 p.p. shock to US Personal income tax rate (PITR) and US Corporate income tax rate (CITR). Bootstrap median estimates with $68 \%$ confidence bands. 


\section{Conclusions}

In this paper we investigate the international dimension of fiscal policy, analyzing the spillover effects of tax rate shocks originating in the US. We study different subcategories of tax shocks, focusing on the international propagation mechanisms and quantifying the size of multipliers. The main finding is that fiscal spillovers are positive and statistically significant, albeit of a relatively small size.

This result suggests some relevant policy insights. First, the potential benefits of a fiscal expansion the US, from the point of view of recipient countries, are generated via the trade channel, which includes both an expenditure boosting and an expenditure switching effect. Second, the international spillovers of US fiscal policy seem to be more relevant for advanced countries than for emerging ones. This is in contrast with the effects of US monetary policy, which is considered a driver for international capital flows and a source of major concern for developing countries. Third, coordination among developed countries for a combined fiscal stimulus would dampen one important channel through which spillovers are transmitted, i.e. real exchange rate movements. As our results show, the international spillover effects are transmitted also through a real exchange rate depreciation in the recipient countries, a channel that would be muted if the fiscal stimulus were

internationally coordinated. In this paper we do not address the question of non-linearity of fiscal policy spillovers, which still deserves further research. 


\section{A Appendix: Estimation Specification and Data Source}

\section{A.1 Estimation Specification}

Here we summarize our model specification in terms of the number of cointegrating relationships and lags chosen. First of all, we conducted the Augmented Dickey-Fuller (ADF) test to check for the presence of unit root for the variables included in the GVAR. At the $5 \%$ significance level, we find that most of the domestic variables are integrated of order 1 , i.e. I(1), with the exception of some variables, mainly interest rate variables, being I(0) or near I(1). The fact that almost all variables show a unit root behavior motivated our choice to proceed in the estimatation of the $N+1$ single country models using the error correction form. In order to recover the cointegrating relationships among variables, we followed the standard Johansen cointegrating procedure; in some cases, we had to reduce the number of cointegrating relationships found by the Johansen test to guarantee the stability of the model, as in Cesa-Bianchi (2013). Concerning the choice of lags in each country model, we followed the Schwarz criterion for the domestic variables, while we impose one lag only for the foreign variables. In some cases, we had to reduce the number of lags for the domestic variables, also to preserve the stability of the model. Results of the tests are available upon request.

\section{A.2 Data source}

The set of variables common to all GVAR models are taken from Mohaddes and Raissi (2018). The database contains data for real GDP $y_{i}$, consumer price inflation $\pi_{i}$, real exchange rate $r_{i}$ (defined as the nominal exchange rate $e_{i}$ minus domestic CPI), the 3-month interest rate $i_{i}^{\text {s }}$, the 10-year government bond yield $i_{i}^{l}$, the real equity price index $q_{i}$ (the equity index deflated by domestic CPI). Exports $\exp _{i}$ are taken from the IMF IFS database. For what concerns the fiscal variables in the United States, we used the following sources. Nominal government spending ( $g c g i)$ is taken from BEA NIPA table 3.1, and consists of both government consumption and investment. Nominal variables are then deflated using the CPI index. The personal income tax rate and tax base, as well as corporate income tax rate and tax base, are taken from the dataset provided by Mertens and Ravn (2013). The narrative series used to identify tax shocks are taken from Mertens and Ravn (2013). 


\section{References}

Auerbach, A. J., Gorodnichenko, Y., May 2013. Output Spillovers from Fiscal Policy. American Economic Review 103 (3), 141-146.

Auerbach, A. J., Gorodnichenko, Y., May 2016. Effects of Fiscal Shocks in a Globalized World. IMF Economic Review 64 (1), 177-215.

Beetsma, R., Giuliodori, M., February 2011. The effects of government purchases shocks: review and estimates for the EU. Economic Journal 121 (550), F4-F32.

Beetsma, R., Giuliodori, M., Klaassen, F., 04-05 2008. The effects of public spending shocks on trade balances and budget deficits in the European Union. Journal of the European Economic Association 6 (2-3), 414-423.

Blagrave, P., Ho, G., Koloskova, K., Vesperoni, E., May 2018. Cross-Border Transmission of Fiscal Shocks: The Role of Monetary Conditions. Imf working papers, International Monetary Fund.

Blanchard, O., Perotti, R., 2002. An Empirical Characterization of the Dynamic Effects of Changes in Government Spending and Taxes on Output. The Quarterly Journal of Economics 117 (4), 1329-1368.

Bussiere, M., Ferrara, L., Juillard, M., Siena, D., 2017. Can fiscal budget-neutral reforms stimulate growth? model-based results. Banque de France Working Paper 625.

Caldara, D., Kamps, C., 05 2017. The Analytics of SVARs: A Unified Framework to Measure Fiscal Multipliers. The Review of Economic Studies 84 (3), 1015-1040.

Caporale, G. M., Girardi, A., 2013. How do us credit supply shocks propagate internationally? a gvarapproach. Journal of International Money and Finance 38, 84.e1-84.e16.

Cesa-Bianchi, A., 2013. Housing cycles and macroeconomic fluctuations: A global perspective. Journal of International Money and Finance 37 (C), 215-238.

URL https://ideas.repec.org/a/eee/jimfin/v37y2013icp215-238.html

Christofzik, D. I., Elstner, S., 2018. International spillover effects of U.S. tax reforms: Evidence from Germany. Tech. rep.

Corsetti, G., Meier, A., Muller, G. J., March 2010. Cross-Border Spillovers from Fiscal Stimulus. International Journal of Central Banking 6 (1), 5-37.

URL https://ideas.repec.org/a/ijc/ijcjou/y2010q1a1.html 
Corsetti, G., Meier, A., Muller, G. J., November 2012a. Fiscal Stimulus with Spending Reversals. The Review of Economics and Statistics 94 (4), 878-895.

Corsetti, G., Meier, A., Muller, G. J., October 2012b. What determines government spending multipliers? Economic Policy 27 (72), 521-565.

Corsetti, G., Muller, G. J., March 2013. Multilateral Economic Cooperation and the International Transmission of Fiscal Policy. In: Globalization in an Age of Crisis: Multilateral Economic Cooperation in the Twenty-First Century. NBER Chapters. National Bureau of Economic Research, Inc, pp. 257-297.

Di Mauro, F., Smith, L. V., Dees, S., Pesaran, M. H., 2007. Exploring the international linkages of the euro area: a global VAR analysis. Journal of Applied Econometrics 22 (1), $1-38$.

Dragomirescu-Gaina, C., Philippas, D., 2015. Strategic interactions of fiscal policies in europe: A global var perspective. Journal of International Money and Finance 59 (C), $49-76$.

Enders, Z., Muller, G. J., Scholl, A., January 2011. How do fiscal and technology shocks affect real exchange rates?: New evidence for the United States. Journal of International Economics 83 (1), 53-69.

Faccini, R., Mumtaz, H., Surico, P., 2016. International fiscal spillovers. Journal of International Economics 99, $31-45$.

Favero, C., Giavazzi, F., Perego, J., November 2011. Country Heterogeneity and the International Evidence on the Effects of Fiscal Policy. IMF Economic Review 59 (4), 652-682.

Forni, M., Gambetti, L., 2016. Government spending shocks in open economy VARs. Journal of International Economics 99 (C), 68-84.

URL https://ideas .repec.org/a/eee/inecon/v99y2016icp68-84.html

Georgiadis, G., 2017. To bi, or not to bi? differences between spillover estimates from bilateral and multilateral multi-country models. Journal of International Economics 107, $1-18$.

Harbo, Ingrid, e. a., October 1998. Asymptotic Inference on Cointegrating Rank in Partial Systems. Journal of Business \& Economic Statistics 16 (4), 388-399.

Hebous, S., Zimmermann, T., 2013. Estimating the effects of coordinated fiscal actions in the euro area. European Economic Review 58 (C), 110-121. 
Ilzetzki, E., Mendoza, E. G., Vegh, C. A., 2013. How big (small?) are fiscal multipliers? Journal of Monetary Economics 60 (2), 239-254.

IMF, 2017. Fiscal spillovers in the euro area: Letting the data speak. IMF working paper 17.

Inoue, T., Kaya, D., Ohshige, H., Oct. 2015. The impact of China?s slowdown on the Asia Pacific region : an application of the GVAR model. Policy Research Working Paper Series 7442, The World Bank.

URL https://ideas.repec .org/p/wbk/wbrwps/7442.html

Jorda, March 2005. Estimation and Inference of Impulse Responses by Local Projections. American Economic Review 95 (1), 161-182.

Kim, S., 2015. Country characteristics and the effects of government consumption shocks on the current account and real exchange rate. Journal of International Economics 97 (2), 436-447.

Kim, S., Roubini, N., March 2008. Twin deficit or twin divergence? Fiscal policy, current account, and real exchange rate in the U.S. Journal of International Economics 74 (2), $362-383$.

Koop, G., Pesaran, M. H., Potter, S. M., September 1996. Impulse response analysis in nonlinear multivariate models. Journal of Econometrics 74 (1), 119-147.

Mertens, K., Ravn, M. O., 2013. The dynamic effects of personal and corporate income tax changes in the united states. American Economic Review 103 (4), 1212-1247.

Mertens, K., Ravn, M. O., 2014. A reconciliation of svar and narrative estimates of tax multipliers. Journal of Monetary Economics 68, 1-19.

Mohaddes, K., Raissi, M., 2018. Compilation, Revision and Updating of the Global VAR (GVAR) Database 1979Q2-2016Q4. University of Cambridge: Faculty of Economics (mimeo).

URL https://ideas.repec.org/a/eee/inecon/v99y2016icp68-84.html

Monacelli, T., Perotti, R., 05 2010. Fiscal Policy, the Real Exchange Rate and Traded Goods. Economic Journal 120 (544), 437-461.

Mountford, A., Uhlig, H., 2009. What are the effects of fiscal policy shocks? Journal of Applied Econometrics 24 (6), 960-992. 
Ong, K., 2018. Do fiscal spending news shocks generate financial spillovers? Economics Letters 164 (C), 46-49.

URL https://ideas.repec.org/a/eee/ecolet/v164y2018icp46-49.html

Pesaran, Schuermann, Weiner, April 2004. Modeling Regional Interdependencies Using a Global Error-Correcting Macroeconometric Model. Journal of Business \& Economic Statistics 22, 129-162.

Pesaran, M. H., Shin, Y., May 1997. Generalised Impulse Response Analysis in Linear Multivariate Models. Cambridge Working Papers in Economics 9710, Faculty of Economics, University of Cambridge.

Pesaran, M. H., Shin, Y., Smith, R. J., August 2000. Structural analysis of vector error correction models with exogenous I(1) variables. Journal of Econometrics 97 (2), 293343.

Ramey, V. A., 2011. Identifying Government Spending Shocks: It's all in the Timing. The Quarterly Journal of Economics 126 (1), 1-50.

Ramey, V. A., Feb. 2016. Macroeconomic Shocks and Their Propagation. NBER Working Papers 21978, National Bureau of Economic Research, Inc.

Ramey, V. A., 2017. Rethinking macroeconomic policy. Peterson Institute for International Economics.

Ravn, M. O., Schmitt-Grohe, S., Uribe, M., 2012. Consumption, government spending, and the real exchange rate. Journal of Monetary Economics 59 (3), 215-234.

Ricci-Risquete, A., Ramajo-Hernandez, J., June 2015. Macroeconomic effects of fiscal policy in the European Union: a GVAR model. Empirical Economics 48 (4), 1587-1617.

Romer, C. D., Romer, D. H., June 2010. The Macroeconomic Effects of Tax Changes: Estimates Based on a New Measure of Fiscal Shocks. American Economic Review 100 (3), 763-801.

Stock, Watson, 2012. Disentangling the channels of the 2007-2009 recession. Brookings Papers on Economic Activity 43 (1), 81-156.

Stock, J. H., Watson, M. W., 2008. Lecture 7: Recent Developments in Structural VAR Modeling. Presented at the National Bureau of Economic Research Summer Institute Minicourse: What's New in Econometrics: Time Series, Cambridge, MA. 


\section{RECENTLY PUBLISHED “TEMI” (*)}

N.1201 - Contagion in the CoCos market? A case study of two stress events, by Pierluigi Bologna, Arianna Miglietta and Anatoli Segura (November 2018).

N. 1202 - Is ECB monetary policy more powerful during expansions?, by Martina Cecioni (December 2018).

N. 1203 - Firms' inflation expectations and investment plans, by Adriana Grasso and Tiziano Ropele (December 2018).

N. 1204 - Recent trends in economic activity and TFP in Italy with a focus on embodied technical progress, by Alessandro Mistretta and Francesco Zollino (December 2018).

N.1205 - Benefits of Gradualism or Costs of Inaction? Monetary Policy in Times of Uncertainty, by Giuseppe Ferrero, Mario Pietrunti and Andrea Tiseno (February 2019).

N.1206 - Machine learning in the service of policy targeting: the case of public credit guarantees, by Monica Andini, Michela Boldrini, Emanuele Ciani, Guido de Blasio, Alessio D'Ignazio and Andrea Paladini (February 2019).

N. 1207 - Do the ECB's monetary policies benefit Emerging Market Economies? A GVAR analysis on the crisis and post-crisis period, by Andrea Colabella (February 2019).

N. 1208 - The Economic Effects of Big Events: Evidence from the Great Jubilee 2000 in Rome, by Raffaello Bronzini, Sauro Mocetti and Matteo Mongardini (February 2019).

N. 1209 - The added value of more accurate predictions for school rankings, by Fritz Schiltz, Paolo Sestito, Tommaso Agasisti and Kristof De Witte (February 2019).

N.1210 - Identification and estimation of triangular models with a binary treatment, by Santiago Pereda Fernández (March 2019).

N. 1211 - U.S. shale producers: a case of dynamic risk management, by Fabrizio Ferriani and Giovanni Veronese (March 2019).

N.1212 - Bank resolution and public backstop in an asymmetric banking union, by Anatoli Segura Velez (March 2019).

N. 1213 - A regression discontinuity design for categorical ordered running variables with an application to central bank purchases of corporate bonds, by Fan Li, Andrea Mercatanti, Taneli Mäkinen and Andrea Silvestrini (March 2019).

N.1214 - Anything new in town? The local effects of urban regeneration policies in Italy, by Giuseppe Albanese, Emanuele Ciani and Guido de Blasio (April 2019).

N. 1215 - Risk premium in the era of shale oil, by Fabrizio Ferriani, Filippo Natoli, Giovanni Veronese and Federica Zeni (April 2019).

N.1216 - Safety traps, liquidity and information-sensitive assets, by Michele Loberto (April 2019).

N. 1217 - Does trust among banks matter for bilateral trade? Evidence from shocks in the interbank market, by Silvia Del Prete and Stefano Federico (April 2019).

N.1218 - Monetary policy, firms' inflation expectations and prices: causal evidence from firm-level data, by Marco Bottone and Alfonso Rosolia (April 2019).

N.1219 - Inflation expectations and firms' decisions: new causal evidence, by Olivier Coibion, Yuriy Gorodnichenko and Tiziano Ropele (April 2019).

N. 1220 - Credit risk-taking and maturity mismatch: the role of the yield curve, by Giuseppe Ferrero, Andrea Nobili and Gabriele Sene (April 2019).

(*) Requests for copies should be sent to:

Banca d'Italia - Servizio Studi di struttura economica e finanziaria - Divisione Biblioteca e Archivio storico - Via Nazionale, 91 - 00184 Rome - (fax 003906 47922059). They are available on the Internet www.bancaditalia.it. 
Aaberge, R., F. Bourguignon, A. Brandolini, F. Ferreira, J. Gornick, J. Hills, M. Jäntti, S. Jenkins, J. Micklewright, E. Marlier, B. Nolan, T. Piketty, W. Radermacher, T. Smeeding, N. Stern, J. Stiglitz, H. Sutherland, Tony Atkinson and his legacy, Review of Income and Wealth, v. 63, 3, pp. 411-444, WP 1138 (September 2017).

AcCetturo A., M. Bugamelli and A. LAmorgese, Law enforcement and political participation: Italy 1861-65, Journal of Economic Behavior \& Organization, v. 140, pp. 224-245, WP 1124 (July 2017).

AdAmopoulou A. and G.M. TANZI, Academic dropout and the great recession, Journal of Human Capital, V. 11, 1, pp. 35-71, WP 970 (October 2014).

Albertazzi U., M. BotTero and G. SENE, Information externalities in the credit market and the spell of credit rationing, Journal of Financial Intermediation, v. 30, pp. 61-70, WP 980 (November 2014).

AlESSANDRI P. and H. MUMTAZ, Financial indicators and density forecasts for US output and inflation, Review of Economic Dynamics, v. 24, pp. 66-78, WP 977 (November 2014).

BARbieri G., C. Rossetti and P. SESTITO, Teacher motivation and student learning, Politica economica/Journal of Economic Policy, v. 33, 1, pp.59-72, WP 761 (June 2010).

Bentivogli C. and M. LitTERIO, Foreign ownership and performance: evidence from a panel of Italian firms, International Journal of the Economics of Business, v. 24, 3, pp. 251-273, WP 1085 (October 2016).

BRONZINI R. and A. D'IGNAZIO, Bank internationalisation and firm exports: evidence from matched firmbank data, Review of International Economics, v. 25, 3, pp. 476-499 WP 1055 (March 2016).

BRUChE M. and A. SEgurA, Debt maturity and the liquidity of secondary debt markets, Journal of Financial Economics, v. 124, 3, pp. 599-613, WP 1049 (January 2016).

Burlon L., Public expenditure distribution, voting, and growth, Journal of Public Economic Theory,, v. 19, 4, pp. 789-810, WP 961 (April 2014).

Burlon L., A. Gerali, A. Notarpietro and M. PisAni, Macroeconomic effectiveness of non-standard monetary policy and early exit. a model-based evaluation, International Finance, v. 20, 2, pp.155173, WP 1074 (July 2016).

BusEtTi F., Quantile aggregation of density forecasts, Oxford Bulletin of Economics and Statistics, v. 79, 4, pp. 495-512, WP 979 (November 2014).

CESARONI T. and S. IEZZI, The predictive content of business survey indicators: evidence from SIGE, Journal of Business Cycle Research, v.13, 1, pp 75-104, WP 1031 (October 2015).

CONTI P., D. MARELLA and A. NERI, Statistical matching and uncertainty analysis in combining household income and expenditure data, Statistical Methods \& Applications, v. 26, 3, pp 485-505, WP 1018 (July 2015).

D’AMURI F., Monitoring and disincentives in containing paid sick leave, Labour Economics, v. 49, pp. 7483, WP 787 (January 2011).

D'AMURI F. and J. MARCUCCI, The predictive power of google searches in forecasting unemployment, International Journal of Forecasting, v. 33, 4, pp. 801-816, WP 891 (November 2012).

DE BLASIO G. and S. POY, The impact of local minimum wages on employment: evidence from Italy in the 1950s, Journal of Regional Science, v. 57, 1, pp. 48-74, WP 953 (March 2014).

Del Giovane P., A. NoBiLi and F. M. SignORETTI, Assessing the sources of credit supply tightening: was the sovereign debt crisis different from Lehman?, International Journal of Central Banking, v. 13, 2, pp. 197-234, WP 942 (November 2013).

Del Prete S., M. PAGNini, P. Rossi and V. VACCA, Lending organization and credit supply during the 2008-2009 crisis, Economic Notes, v. 46, 2, pp. 207-236, WP 1108 (April 2017).

Delle Monache D. and I. Petrella, Adaptive models and heavy tails with an application to inflation forecasting, International Journal of Forecasting, v. 33, 2, pp. 482-501, WP 1052 (March 2016).

FEDERICO S. and E. TOSTI, Exporters and importers of services: firm-level evidence on Italy, The World Economy, v. 40, 10, pp. 2078-2096, WP 877 (September 2012).

Giacomelli S. and C. MENON, Does weak contract enforcement affect firm size? Evidence from the neighbour's court, Journal of Economic Geography, v. 17, 6, pp. 1251-1282, WP 898 (January 2013).

Loberto M. and C. Perricone, Does trend inflation make a difference?, Economic Modelling, v. 61, pp. 351-375, WP 1033 (October 2015). 
MANCINI A.L., C. MonfARdini and S. PASQUA, Is a good example the best sermon? Children's imitation of parental reading, Review of Economics of the Household, v. 15, 3, pp 965-993, D No. 958 (April 2014).

MEEKS R., B. NELSON and P. AlessANDRI, Shadow banks and macroeconomic instability, Journal of Money, Credit and Banking, v. 49, 7, pp. 1483-1516, WP 939 (November 2013).

MiCUCCI G. and P. Rossi, Debt restructuring and the role of banks' organizational structure and lending technologies, Journal of Financial Services Research, v. 51, 3, pp 339-361, WP 763 (June 2010).

Mocetti S., M. PAGNini and E. SETTE, Information technology and banking organization, Journal of Journal of Financial Services Research, v. 51, pp. 313-338, WP 752 (March 2010).

MocetTi S. and E. ViVIANO, Looking behind mortgage delinquencies, Journal of Banking \& Finance, v. 75, pp. 53-63, WP 999 (January 2015).

NoBili A. and F. Zollino, A structural model for the housing and credit market in Italy, Journal of Housing Economics, v. 36, pp. 73-87, WP 887 (October 2012).

PALAZzO F., Search costs and the severity of adverse selection, Research in Economics, v. 71, 1, pp. 171197, WP 1073 (July 2016).

Patacchini E. and E. Rainone, Social ties and the demand for financial services, Journal of Financial Services Research, v. 52, 1-2, pp 35-88, WP 1115 (June 2017).

PATACCHINI E., E. RAINONE and Y. ZENOU, Heterogeneous peer effects in education, Journal of Economic Behavior \& Organization, v. 134, pp. 190-227, WP 1048 (January 2016).

SBrana G., A. Silvestrini and F. VenditTI, Short-term inflation forecasting: the M.E.T.A. approach, International Journal of Forecasting, v. 33, 4, pp. 1065-1081, WP 1016 (June 2015).

SEgurA A. and J. SuAREZ, How excessive is banks' maturity transformation?, Review of Financial Studies, v. 30, 10, pp. 3538-3580, WP 1065 (April 2016).

VACCA V., An unexpected crisis? Looking at pricing effectiveness of heterogeneous banks, Economic Notes, v. 46, 2, pp. 171-206, WP 814 (July 2011).

Vergara CAFFAReli F., One-way flow networks with decreasing returns to linking, Dynamic Games and Applications, v. 7, 2, pp. 323-345, WP 734 (November 2009).

ZAGHINI A., A Tale of fragmentation: corporate funding in the euro-area bond market, International Review of Financial Analysis, v. 49, pp. 59-68, WP 1104 (February 2017).

Accetturo A., v. Di Giacinto, G. Micucci and M. Pagnini, Geography, productivity and trade: does selection explain why some locations are more productive than others?, Journal of Regional Science, v. 58, 5, pp. 949-979, WP 910 (April 2013).

AdAmopoulou A. and E. KAYA, Young adults living with their parents and the influence of peers, Oxford Bulletin of Economics and Statistics,v. 80, pp. 689-713, WP 1038 (November 2015).

ANDini M., E. Ciani, G. DE Blasio, A. D'Ignazio and V. Silvestrini, Targeting with machine learning: an application to a tax rebate program in Italy, Journal of Economic Behavior \& Organization, v. 156, pp. 86-102, WP 1158 (December 2017).

BARONE G., G. DE BLASIO and S. MOCETTI, The real effects of credit crunch in the great recession: evidence from Italian provinces, Regional Science and Urban Economics, v. 70, pp. 352-59, WP 1057 (March 2016).

Belotti F. and G. IlARDI Consistent inference in fixed-effects stochastic frontier models, Journal of Econometrics, v. 202, 2, pp. 161-177, WP 1147 (October 2017).

Berton F., S. Mocetti, A. Presbitero and M. Richiardi, Banks, firms, and jobs, Review of Financial Studies, v.31, 6, pp. 2113-2156, WP 1097 (February 2017).

Bofondi M., L. CARPInElli and E. SETTE, Credit supply during a sovereign debt crisis, Journal of the European Economic Association, v.16, 3, pp. 696-729, WP 909 (April 2013).

BokAn N., A. Gerali, S. Gomes, P. JACQUINOT and M. PISANI, EAGLE-FLI: a macroeconomic model of banking and financial interdependence in the euro area, Economic Modelling, v. 69, C, pp. 249280, WP 1064 (April 2016). 
BRILli Y. and M. TONELlo, Does increasing compulsory education reduce or displace adolescent crime? New evidence from administrative and victimization data, CESifo Economic Studies, v. 64, 1, pp. 15-4, WP 1008 (April 2015).

BUONO I. and S. FORMAI The heterogeneous response of domestic sales and exports to bank credit shocks, Journal of International Economics, v. 113, pp. 55-73, WP 1066 (March 2018).

Burlon L., A. GERAli, A. NotARPIETRO and M. PisAnI, Non-standard monetary policy, asset prices and macroprudential policy in a monetary union, Journal of International Money and Finance, v. 88, pp. 25-53, WP 1089 (October 2016).

CARTA F. and M. DE PHLIPPIS, You've Come a long way, baby. Husbands' commuting time and family labour supply, Regional Science and Urban Economics, v. 69, pp. 25-37, WP 1003 (March 2015).

CARTA F. and L. RIzZICA, Early kindergarten, maternal labor supply and children's outcomes: evidence from Italy, Journal of Public Economics, v. 158, pp. 79-102, WP 1030 (October 2015).

Casiraghi M., E. Gaiotti, L. Rodano and A. Secchi, A "Reverse Robin Hood”? The distributional implications of non-standard monetary policy for Italian households, Journal of International Money and Finance, v. 85, pp. 215-235, WP 1077 (July 2016).

CECChetti S., F. NATOLI and L. SigAlotTI, Tail co-movement in inflation expectations as an indicator of anchoring, International Journal of Central Banking, v. 14, 1, pp. 35-71, WP 1025 (July 2015).

CIANI E. and C. DEIANA, No Free lunch, buddy: housing transfers and informal care later in life, Review of Economics of the Household, v.16, 4, pp. 971-1001, WP 1117 (June 2017).

Cipriani M., A. Guarino, G. Guazzarotti, F. TAgliati and S. Fisher, Informational contagion in the laboratory, Review of Finance, v. 22, 3, pp. 877-904, WP 1063 (April 2016).

De Blasio G, S. De Mitri, S. D’Ignazio, P. Finaldi Russo and L. Stoppani, Public guarantees to SME borrowing. A RDD evaluation, Journal of Banking \& Finance, v. 96, pp. 73-86, WP 1111 (April 2017).

Gerali A., A. LocARno, A. NotArPIETRO and M. PISANI, The sovereign crisis and Italy's potential output, Journal of Policy Modeling, v. 40, 2, pp. 418-433, WP 1010 (June 2015).

LIBERATI D., An estimated DSGE model with search and matching frictions in the credit market, International Journal of Monetary Economics and Finance (IJMEF), v. 11, 6, pp. 567-617, WP 986 (November 2014).

Linarello A., Direct and indirect effects of trade liberalization: evidence from Chile, Journal of Development Economics, v. 134, pp. 160-175, WP 994 (December 2014).

NuCCI F. and M. RIGgI, Labor force participation, wage rigidities, and inflation, Journal of Macroeconomics, v. 55, 3 pp. 274-292, WP 1054 (March 2016).

RIGON M. and F. ZANETTI, Optimal monetary policy and fiscal policy interaction in a non_ricardian economy, International Journal of Central Banking, v. 14 3, pp. 389-436, WP 1155 (December 2017).

SEGURA A., Why did sponsor banks rescue their SIVs?, Review of Finance, v. 22, 2, pp. 661-697, WP 1100 (February 2017).

ARnAudo D., G. MiCUCCI, M. RIGON and P. Rossi, Should I stay or should I go? Firms' mobility across banks in the aftermath of the financial crisis, Italian Economic Journal / Rivista italiana degli economisti, v. 5, 1, pp. 17-37, WP 1086 (October 2016).

CIANI E., F. DAVID and G. DE BLASIO, Local responses to labor demand shocks: a re-assessment of the case of Italy, Regional Science and Urban Economics, v. 75, pp. 1-21, WP 1112 (April 2017).

CIANI E. and P. FISHER, Dif-in-dif estimators of multiplicative treatment effects, Journal of Econometric Methods, v. 8. 1, pp. 1-10, WP 985 (November 2014).

Chiades P., L. Greco, V. Mengotto, L. Moretti and P. Valbonesi, Fiscal consolidation by intergovernmental transfers cuts? The unpleasant effect on expenditure arrears, Economic Modelling, v. 77, pp. 266-275, WP 985 (July 2016). 
Giordano C., M. MARINUCCI and A. SiLveSTRINI, The macro determinants of firms' and households' investment: evidence from Italy, Economic Modelling, v. 78, pp. 118-133, WP 1167 (March 2018).

MONTEFORTE L. and V. RAPONI, Short-term forecasts of economic activity: are fortnightly factors useful?, Journal of Forecasting, v. 38, 3, pp. 207-221, WP 1177 (June 2018).

RigGi M., Capital destruction, jobless recoveries, and the discipline device role of unemployment, Macroeconomic Dynamics, v. 23, 2, pp. 590-624, WP 871 (July 2012).

\section{FORTHCOMING}

Albanese G., G. DE Blasio and P. Sestito, Trust, risk and time preferences: evidence from survey data, International Review of Economics, WP 911 (April 2013).

Aprigliano V., G. ARDIZZI and L. MONTEFORTE, Using the payment system data to forecast the economic activity, International Journal of Central Banking, WP 1098 (February 2017).

ARDUINI T., E. PATACCHINI and E. RAINONE, Treatment effects with heterogeneous externalities, Journal of Business \& Economic Statistics, WP 974 (October 2014).

BElotti F. and G. ILARDI, Consistent inference in fixed-effects stochastic frontier models, Journal of Econometrics, WP 1147 (October 2017).

BusetTi F. and M. CAIVANO, Low frequency drivers of the real interest rate: empirical evidence for advanced economies, International Finance, WP 1132 (September 2017).

Cappelletti G., G. Guazzarotti and P. Tommasino, Tax deferral and mutual fund inflows: evidence from a quasi-natural experiment, Fiscal Studies, WP 938 (November 2013).

CIANI E. and G. DE BLASIO, European structural funds during the crisis: evidence from Southern Italy, IZA Journal of Labor Policy, WP 1029 (October 2015).

COletta M., R. De Bonis and S. PIERMATteI, Household debt in OECD countries: the role of supply-side and demand-side factors, Social Indicators Research, WP 989 (November 2014).

CORSELlO F. and V. NISPI LANDI, Labor market and financial shocks: a time-varying analysis, Journal of Money, Credit and Banking, WP 1179 (June 2018).

Cova P., P. PAGANO and M. PISANI, Domestic and international macroeconomic effects of the Eurosystem Expanded Asset Purchase Programme, IMF Economic Review, WP 1036 (October 2015).

D’AMURI F., Monitoring and disincentives in containing paid sick leave, Labour Economics, WP 787 (January 2011).

D'Ignazio A. and C. MENOn, The causal effect of credit Guarantees for SMEs: evidence from Italy, Scandinavian Journal of Economics, WP 900 (February 2013).

ERCOLANi V. and J. VAlle E AzEVEDO, How can the government spending multiplier be small at the zero lower bound?, Macroeconomic Dynamics, WP 1174 (April 2018).

FEDERICO S. and E. TOSTI, Exporters and importers of services: firm-level evidence on Italy, The World Economy, WP 877 (September 2012).

GERAli A. and S. NeRI, Natural rates across the Atlantic, Journal of Macroeconomics, WP 1140 (September 2017).

Giacomelli S. and C. Menon, Does weak contract enforcement affect firm size? Evidence from the neighbour's court, Journal of Economic Geography, WP 898 (January 2013).

NAtoli F. and L. SigalotTI, Tail co-movement in inflation expectations as an indicator of anchoring, International Journal of Central Banking, WP 1025 (July 2015).

RAINONE E., The network nature of otc interest rates, Journal of Financial Markets, WP 1022 (July 2015).

RIZZICA L., Raising aspirations and higher education. evidence from the UK's widening participation policy, Journal of Labor Economics, WP 1188 (September 2018).

SEGURA A., Why did sponsor banks rescue their SIVs?, Review of Finance, WP 1100 (February 2017). 